Document downloaded from:

http://hdl.handle.net/10251/117971

This paper must be cited as:

González Sanchís, MDC.; Ruiz Perez, G.; Garcia-Prats, A.; Campo García, ADD.; Francés, F.; Lull, C. (2019). Managing low productive forests at catchment scale: Considering water, biomass

and fie risk to achieve economic feasibility. Journal of Environmental Management. 231:653665. https://doi.org/10.1016/j.jenvman.2018.10.078

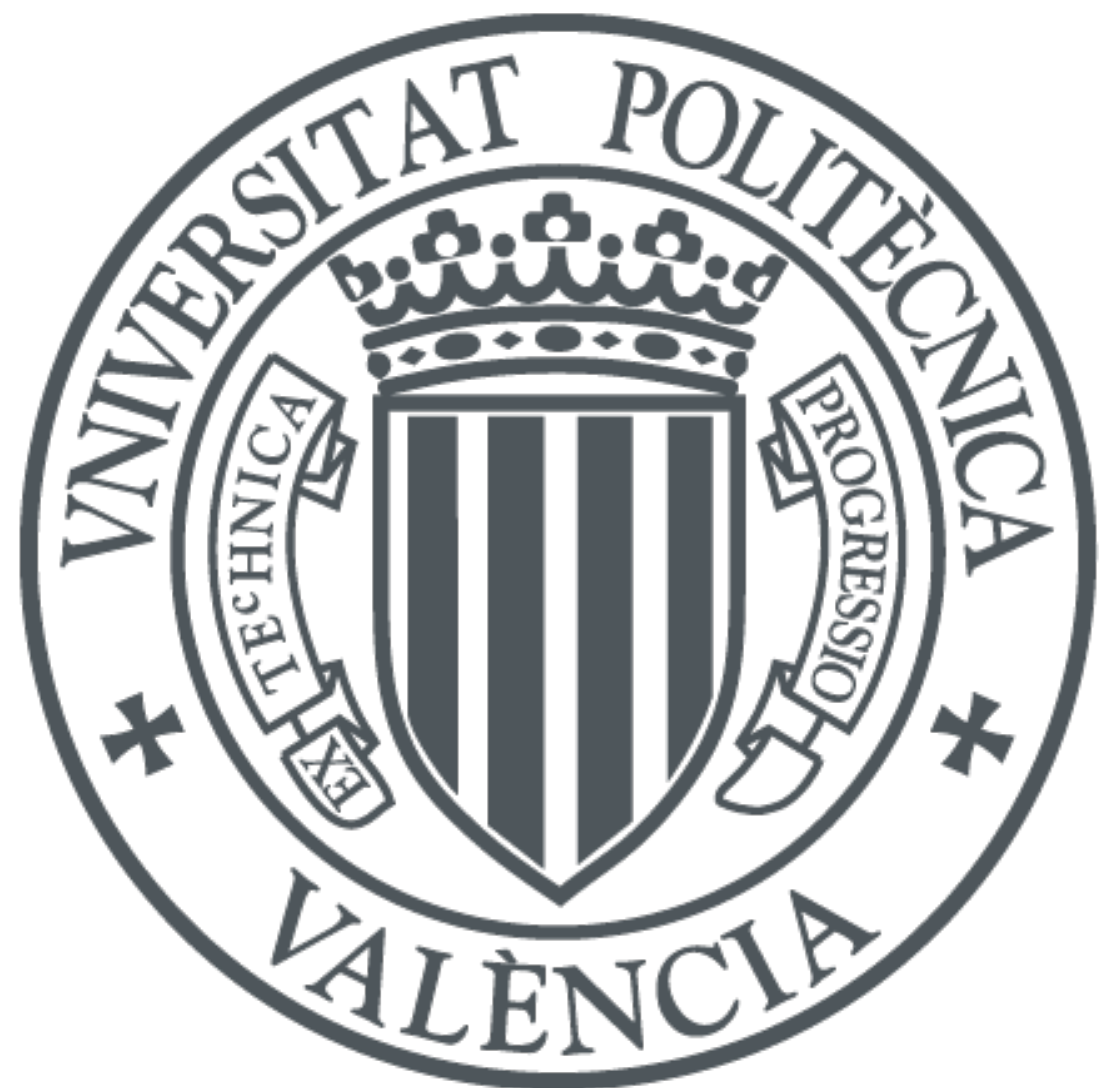

The final publication is available at

https://doi.org/10.1016/j.jenvman.2018.10.078

Copyright Elsevier

Additional Information 


\title{
Managing low productive forests at catchment scale: considering water, biomass and fire risk to achieve economic feasibility
}

\author{
María González-Sanchis ${ }^{1 *}$, Guiomar Ruiz-Pérez ${ }^{2}$, Antonio D. Del Campo ${ }^{1}$, Alberto \\ Garcia-Prats $^{1}$, Félix Francés ${ }^{3}$, Cristina Lull ${ }^{1 *}$ \\ 1: Research Group in Forest Science and Technology (Re-ForeST), Research Institute of Water \\ and Environmental Engineering (IIAMA), Universitat Politècnica de València, Spain. \\ 2: Department of Crop Production Ecology, Swedish University of Agricultural Sciences (SLU), \\ Uppsala, Sweden. \\ 3: Research Group of Hydrological and Enviromental Modelling (GIMHA), Research Institute of \\ Water and Environmental Engineering (IIAMA), Universitat Politècnica de València, Spain.
}

\section{Abstract}

Semi-arid forests are water limited environments considered as low-productive. As a result, these forests usually end up unmanaged and abandoned, with the subsequent wild fire risk increasing, water yield decreasing and a general diminishing of the forest resilience. Hydrological-oriented silviculture could be a useful alternative that increases management possibilities by combining forest productivity and water yield. However, the slight water yield increase after forest management together with the low forest productivity, could make this option insufficient for semi-arid forests, and other goods and services should be included and quantified. In this sense, the present study analyzes to what extent semi-arid forest management for water yield results effective and profitable at catchment scale, and how does it improve when it is combined with other benefits such as biomass production and fire risk diminishing. To that end, the effects of forest management of semi-arid Aleppo pine post-fire re-

\footnotetext{
*Corresponding Author: macgonsa@gmail.com.
} 
generation stands are analyzed in terms of water yield (TETIS-VEG model), fire risk (KDBY index and FARSITE) and biomass production, at catchment scale. Regarding to water yield, the results confirmed the slight effect of forest management on its increase (average increase of $0.27 \pm 0.29 \mathrm{~mm} \cdot \mathrm{yr}^{-1}$ ), at the same time that highlighted the role of the upper catchment area as an important water contributor. The management produced 4161.6 Mg of biomass, and decreased in $27 \pm 17 \%$ and $25.6 \pm 14.1$ $\%$ the fire risk and fire propagation, respectively. Finally, a simple economic estimation of the management profitability is carried out by means of comparing the Benefit/Cost ratio of the managed and unmanaged scenarios. Both scenarios were always above the unity when just considering water as benefit, although the unmanged scenario produced a higher ratio, as no management costs are expended. Contrarily, when wildfire was also included into the evaluation, the situation is overturned for wildfires equal or higher than 1.5 day duration, where the forest management is shown as the most convenient alternative.

Keywords: Water scarcity, forest management, wild fire risk, hydrological modeling, profitability, forest ecosystem services.

\section{Introduction}

Forests influence the amount of available water and regulate surface and groundwater flows while maintaining high water quality. Particularly, water availability in water-scarcity prone areas, such as the Mediterranean basin, is mainly dependent on runoff from mountain forest areas, which can contribute 50-90\% of the total yield (Liniger et al., 1998; Liniger and Weingartner, 2000; Viviroli et al., 2003). In spite of the important water contribution, the traditional forest management approach, which is mainly focused on productive functions (timber, pulp, cork, etc), considers these forests as low-productive, and they usually end up unmanaged and abandoned 
(Fabbio et al., 2003). As a result, these forests are expanded and densified at the same time that the water contribution decreases (Filoso et al., 2017). Some studies have reported a decrease in the average annual flow in some major Spanish rivers between 37 and $59 \%$, partly explained by the expansion and densification of upstream forests (Rambal, 1987; Gallart and Llorens, 2003, 2004). Furthermore, forest densification highly increases the wild fire risk and propagation (Viedma et al., 2015), which can cause great damage that has ecological, social and economic consequences, specially when dealing with the wild land-urban interfaces (Lampin-Maillet et al. 2010), a common landscape of the Mediterranean upper catchment environments. The streamflow reduction and the wildfire risk increasing together with the climate change projections that predict an increase of water scarcity in the Mediterranean area (Giorgi, 2006), enhance the need of a proper forest management that reduces and prevents from forest densification of upper catchment environments.

Water-oriented silviculture is conceived as a strategy that increases water availability by modifying the forest structure (Swanson et al., 1984; Molina and del Campo, 2012). For much of the 20th century, water yield increasing has been one goal of management and research (Hibbert, 1965, Bosch and Hewlett, 1982; Troendle, 1983; Troendle et al., 2001; Mark and Dickinson, 2008; McLaughlin et al., 2013). Its success is strongly influenced by the climatic conditions Stogsdili Jr et al. (1992), ¿ which sharply decreases when moving from humid to semi-arid environments Bosch and Hewlett, 1982). In this sense, Bosch and Hewlett (1982) reported a study case where the management of a spruce forest with an annual precipitation of $265 \mathrm{~mm}$ only increased the water yield in $58 \mathrm{~mm}$ in 5 years. Likewise, Simonin et al. (2007) analyzed the effects of forest management of a Ponderosa pine forest stand during and after extreme drought on aquifer recharge and obtained no recharge of water 
into soil below the rooting zone or to ground water. Similar results were obtained by González-Sanchis et al. (2015), where forest management under low precipitation values $(188 \mathrm{~mm})$ only increased the water yield in $14.6 \mathrm{~mm}$ per year. Thus, managing water-scarce forests to increase water budget may not rise enough the water yield to make the management profitable, being necessary to address further goods/services in order to ground eco-hydrology-oriented silviculture.

Forest management increases forest productivity, but it also contributes to reduce wild fire risk (De Cáceres et al., 2015), increases ecosystem resilience (Millar et al. 2007), increases water availability (Stoneman, 1993; Callegari et al., 2003; Simonin et al. 2007; Molina and del Campo, 2012), improves tree growth and vigor (Mitchell et al., 1983; Pulido et al., 2001; Olivar et al., 2013), landscape value (Maroto et al., 2013), etc. The relevance of each good and service does not only depend on the local forest conditions, but also on the ecological and social-economy needs of the catchment. Thus in order to make possible the management of low-productive forests, these goods and services must be quantified within the ecological and social-economy context of the catchment (Duncker et al., 2012). In this sense, several studies have quantified other goods and services besides timber according to the catchment needs (Başkent et al., 2011; Keleş and Başkent, 2011; Küçüker and Baskent, 2015; Susaeta et al., 2017), but they are almost always developed in humid or sub-humid environments where either water availability nor forest productivity are problematic. Thus, as productive forests, timber is usually included as the main management goal, where other goods and services such as water are considered as complementary. On the other hand, when water yield is quantified, it is usually computed at stand scale, where the possible blurring effect when moving from stand to catchment scale is neglected (Wyatt et al., 2015). Just few studies have been developed in low-productive 
forests. Garcia-Prats et al. (2016) combined timber production with water yield of a semi-arid afforestation as a strategy to promote its management, but the authors computed the water contribution at stand scale instead of at catchment scale. Ovando et al. (2018) quantified water yield and carbon sequestration at regional scale, and although some semi-arid low-productive forests where included, since most of the domain was occupied by productive forests, the general balance was dominated by these productive areas. Likewise, Simonit et al. (2015) analyzed the effects of thinning on water contribution of a semi-arid catchment, and despite the fact that the water yield computing was at catchment scale, no management costs nor timber and/or biomass revenues were included into the analysis, leaving still unanswered the question about the profitability of semi-arid low-productive forest management. This study aims to fill this gap analyzing the effectiveness and profitability of the management of a semi-arid low-productive forest at catchment scale.

Considering the benefits of forest management at catchment scale, makes it necessary the use of eco-hydrological models capable of reproducing not only the hydrological connectivity of the catchment, but also the dynamics of each vegetation type. Process-based models such as BIOME-BGC (Thornton et al., 2002), GOTILWA (Gracia et al., 1999), HYDRALL (Magnani et al., 2004) or FORGRO (Mohren, 1987; Mohren et al., 1993) are usually a good alternative to reproduce the hydrological and biological dynamics of the vegetation Kramer et al., 2002, Sabaté et al., 2002; Cienciala and Fyodor, 2006; Tatarinov and Cienciala, 2006; Magnani et al., 2009: Chiesi et al., 2011; Eastaugh et al., 2011; González-Sanchis et al., 2015). However, even though their high accuracy, these models are designed to fine spatial scales, not being thus suitable for reproducing accurately the whole catchment dynamics. In addition to scale limitations, the important amount of coefficients that are usually 
required in these models also limits their applicability (Quevedo and Francés, 2007). This represents a particularly challenging task, especially considering that in operational applications the available information is frequently quite limited, in particular for arid and semi-arid regions which often could be categorized as ungauged basins Andersen, 2008). In this sense, the use of parsimonious models reduces considerably the number of the required coefficients at the same time that reproduces the hydrological and vegetation dynamics of the catchment. Its is also true that the accuracy of the results might not be as high as that of more complex models, but it is not necessary due to the model itself, but also to the different used spatial scales. Ruiz-Pérez et al. (2016) compared the performance at plot scale of BIOME-BGC to that of the parsimonious and dynamic vegetation LUE-model proposed by Pasquato et al. (2015), obtaining very similar results with both models, which indicates the spatial scale factor as an important influential element on the model accuracy.

For all these reasons, this study aims to analyze to what extent semi-arid forest management for water yield results effective and profitable at catchment scale, and how does it improve when it is combined with other benefits such as biomass production and fire risk diminishing. At the same time, this study proposes the parsimonious TETIS-VEG model Ruiz-Pérez et al. (2017) for eco-hydrology-oriented silviculture at catchment scale. The specific objectives of the study are:

- Analyzing the performance of TETIS-VEG model as a tool for eco-hydrological forest management.

- Examining and quantify the early effects and profitability of semi-arid forest management for water yield at catchment scale.

- Analyzing and quantifying the early effects and profitability of a multi-purpose 
forest management approach that includes water contribution, biomass production and fire risk and propagation decreasing at catchment scale.

To achieve these objective, this study first implements the model TETIS-VEG, to analyze the early effects of forest management on the hydrological contribution of the mountainous Carraixet's upper basin. Then, the biomass production derived from forest management is quantified. Finally, fire risk and propagation are also analyzed under both scenarios, managed and unmanaged. These results are quantified in terms of direct benefits (water yield, biomass and fire risk and propagation) and economically.

\section{Study site}

The study site is located in the upper part of Carraixet catchment (E of Spain), which has an extension of 84942 ha, and 11901 ha correspond to its upper part. It is a mountainous area located between the provinces of Castellón and Valencia, in the Mediterranean coast of Spain, where $64 \%$ of its territory is included within the Natural Park of Sierra Calderona (Fig. 1). Carraixet's upper area faces SW, its elevation ranges from 250 to 1000 m.a.s.l., and it has a typical Mediterranean climate with a mean annual temperature of $17^{\circ} \mathrm{C}$ (between the years 1960-2007), an annual potential evapotranspiration of $837 \mathrm{~mm}$ (between the years 1960-1990 using Thornthwaite), and a highly irregular mean annual rainfall that ranges from 350 to 600 mm (between the years 1960-2007), with intense autumn storms and dry summers. Nevertheless, during the last 17 years, the registered precipitation is $300 \pm 76 \mathrm{~mm}$. The climate is classified as Mediterranean semiarid according to the De Martonne aridity index (De Martonne, 1926) or Thornthwaite (1948). Soils are generally shallow (approximately 30-60 cm deep) where limestones, dolomites and loams occupy 
the main part of the territory. The area is mainly occupied by Pinus halepensis Mill. (Aleppo pine) forests and shrub-lands, although it is also possible to find a few forest gaps of Quercus ilex sbsp. ballota, Quercus suber and Pinus pinaster. In the same way, there are some scattered rain-fed agricultural fields, which have been progressively abandoned.

[Figure 1 about here.]

Carraixet's catchment includes 15 populations, 6 (35 932 inhabitants) of which are located within the mountainous area (Fig. 1), whose main water source (drinking water and agricultural irrigation) is the groundwater. The main water contribution is produced by deep percolation, as runoff phenomenon is of low frequency $(1.1 \%)$ and duration (1 to 3 days). The rest of the populations (9) use water from two catchments, Carraixet and Túria, and its distribution depends on the water availability.

Sierra Calderona has historically suffered wild fires as lightning is highly frequent here (one of the most frequent zones in Spain), and agricultural field burning practices are very common in its rural areas. The last big wildfire that took place in Sierra Calderona was in August 1992, and it burned an area of 9498 ha, where 6007 ha were mainly occupied by typical Aleppo pine forest (Rubio et al., 1997). After this fire, just within the upper Carraixet catchment 27 more wild fires (burned area $\geq 1$ ha) have been registered, with a frequency of 1.1 fire/year, an average burned area of $84.8 \pm 277.3 \mathrm{ha}$, and an average duration of $1 \pm 5 \mathrm{~h}$. Wildfires produce an abundance of post-fire naturally regenerated areas, where Aleppo pine is the most important species in low elevation areas due to its broad geographic extension and high ecological value from adaptive strategies to fire (Quezel, 2000; Nathan and Ne'eman, 2004). 
Nevertheless, after 28 wildfires in 25 years, the recovering of the vegetation becomes very difficult as the soils quality is significantly diminished. As a result, just in 272 ha out of the burned 9498 ha, Aleppo pine post-fire regeneration stands can be observed. These stands are 24 years old, have a tree density that ranges from 5500 to 19200 trees ha ${ }^{-1}$, and forest management (juvenile thinning) has only been applied to 22 ha.

\section{Material and Methods}

This paper uses the parsimonious and dynamic vegetation TETIS-VEG model proposed by Ruiz-Pérez et al. (2017) to analyze the effectiveness of forest management of Aleppo pine post-fire regeneration stands to increase water yield at catchment scale. First the model is calibrated and evaluated by using both, field measurements (soil moisture and transpiration) and satellite information (soil temperature from Landsat 8 OLI/TIRS Data). Then, the model is applied to simulate 10 different water years (2007-2017) to obtain the hydrological contribution of the upper basin with and without forest management. Subsequently, a multi-purpose forest management approach that includes water, biomass and fire risk and propagation, is proposed and analyzed (see Figure 2). Finally, the profitability of the multi-purpose forest management approach is analyzed by comparing the Benefit/Cost ratio with that of the unmanaged situation.

[Figure 2 about here.]

\subsection{Field measurements}

This study uses daily field data from two experimental plots of Aleppo pine postfire regeneration only for the validation of TETIS-VEG model. In a representative 
area, one plot, control, was left with no forest management, and a contiguous managed plot, treatment, was established. The applied forest management (October 2012) consisted of a thinning that reduced the initial tree density of 11300 to 703 tree ha ${ }^{-1}$. The Canopy Cover (CC) was reduced form 79 to $39 \%$, and the basal area from 17.5 to $8.5 \mathrm{~m}^{2} \mathrm{ha}^{-1}$. Control and treatment plots were of $1500 \mathrm{~m}^{2}$ area respectively, both NW oriented and divided into 3 replicates or experimental blocks from up-slope to down-slope in order to assure representative result. More details about the experimental design can be found in del Campo et al. (2018). Among other variables, gross rainfall $(\mathrm{Gr})$, soil moisture (SM) and sap-flow were continuously registered in both plots from October, 1, 2013 to September, 30, 2016. Gr was continuously measured by means of a tipping-bucket rain gauge with $0.2 \mathrm{~mm}$ resolution (Davis 7852). SM was continuously measured for the whole period every 10 minutes, or every $5 \mathrm{sec}$ when raining, by means of FDR (frequency domain reflectometry) probes (EC-5, Decagon Devices Inc., Pullman, WA). Sensors were installed by digging three pits per block (9 per plot) along contour lines. In the central pit of each block, three sensors were horizontally poked at depths of 5, 15 and $30 \mathrm{~cm}$ into the unaltered up-slope pit face, whereas in the other two pits, only one sensor was inserted at $15 \mathrm{~cm}$ deep. Total sample size per plot (treated/control) was 15 sensors in 9 spots. Sap-flow was measured in Aleppo pine by means of sap-flow sensors based on heat ratio method (Burgess et al., 2001) in 9 trees per plot (3 per replicate) according to the frequency distribution of diameters. To up-scale the sap-flow to stand transpiration $(\mathrm{T}, \mathrm{mm})$, first the average sap-flow tree $\left(\mathrm{SF}_{\text {tree }}, \mathrm{l}\right.$ tree $\left.{ }^{-1}\right)$ was obtained by means of the weighting average according to the frequency distribution of diameters. Subsequently, this value was up-scaled by using the tree crown projected area $\left(\mathrm{CPA}, \mathrm{m}^{2}\right.$ tree $\left.^{-1}\right)$ as scalar, and correcting it with the plot forest cover (FC) as follows: 


$$
T=S F_{\text {tree }} \cdot \frac{1}{C P A} \cdot F C
$$

\subsection{Modeling}

\subsubsection{TETIS-VEG model description}

TETIS-VEG is the result of coupling a dynamic vegetation model to the distributed hydrological model called TETIS (Francés et al., 2007). Both, hydrological and vegetation sub-models, have simplicity of model structure in common (i.e. the used equations are as simple as possible in order to reduce the number of parameters). The sub-models are interconnected through transpiration and soil water content. In particular, the transpiration calculated in the hydrological sub-model depends on the LAI simulated by the dynamic vegetation sub-model. At the same time, the simulated LAI is affected by water stress, which is calculated using the hydrological sub-model. The TETIS-VEG model has been already successfully applied in water-controlled environments (Ruiz-Pérez et al., 2016; Ruiz-Pérez et al., 2017).

Hydrological sub-model. TETIS's conceptual scheme consists of a series of connected reservoirs, each one representing different water storage in the soil column: (i) vegetation interception, (ii) first static soil layer (retained water by upper soil capillary forces, i.e., below field capacity plus water detention in surface puddles; evaporation and transpiration can occur), (iii) second static soil layer (retained water in deeper soil by capillary forces; only transpiration can occur), (iv) surface (for overland runoff), (v) gravitational soil layer (upper soil water content above field capacity for interflow) and (vi) aquifer (for river baseflow). Vertical connections between reservoirs describe the precipitation, evaporation from bare soil, transpiration, infiltration and percolation processes (Figure 3). The horizontal flows describe the three different hydrological responses that give the discharge at the catchment outlet: overland 
runoff, interflow and baseflow. A more detailed description of the TETIS model can be found in Francés et al. (2007) and GIMHA (2014).

[Figure 3 about here.]

The hydrological and vegetation sub-models are interconnected through transpiration and soil moisture. Concretely, the transpiration is obtained using the reference evapotranspiration $\left(\mathrm{ET}_{0}\right)$ multiplied by a water stress factor $(\zeta)$ and by a factor related to the current leaf area index (LAI) simulated by the dynamic vegetation sub-model, as shown in Eq. 2. Through this factor, the state of vegetation affects the hydrological fluxes and, consequently, the water storage in the different tanks.

$$
T_{i}=\left(E T_{0}-E I\right) \cdot \min (1, L A I) \cdot \zeta \cdot Z_{i}
$$

where $T_{i}$ is the transpiration from the $i$ soil layer, EI is the evaporation of the intercepted water and $Z_{i}$ is the percentage of roots in the i soil layer. The expression $\min (1, \mathrm{LAI})$ is the factor which replaces the crop factor recommended by the FAO 56 . The percentage of roots determines the proportion of water that is transpired from the first/second static soil layer. The value of this parameter was different between land use types and the same within each land use type, and was therefore included in the calibration process.

Vegetation sub-model. The proposed dynamic vegetation sub-model is based on the concept of light use efficiency (LUE; Medlyn (1998)) and calculates the leaf biomass $\left(\mathrm{B}_{l}\right)$ according to the Eq. 3. The LUE is the proportionality between plant biomass production by terrestrial vegetation and absorbed photosynthetically active radiation (APAR) in optimal conditions. However, the LUE can be strongly affected by stress 
conditions. The key factors contributing to the variation of this efficiency are: soil moisture content, air temperature (Landsberg and Waring, 1997; Sims et al., 2006) and nutrient levels (Gamon et al., 1997; Ollinger et al., 2008). Since this model is designed to be used in water-controlled areas, nutrient limitation for growth can be overall neglected because water availability is the main limiting factor, and therefore the nutrient levels are not considered.

$$
\frac{d B_{l}}{d t}=(L U E \cdot \epsilon \cdot P P F D \cdot f P P F D-R e) \cdot \varphi_{l}-k_{l} \cdot B_{l}
$$

where $\mathrm{B}_{l}$ is the leaf biomass, LUE is the above-mentioned light use efficiency, $\epsilon$ is the water stress factor, PPFD is the photosynthetic photon flux density, fPPFD is the fraction of photosynthetic photon flux density, Re is the respiration, $\varphi_{l}\left(\mathrm{~B}_{l}\right)$ is the fractional leaf allocation, and $\mathrm{k}_{l}$ is the leaf natural decay factor to reproduce the senescence. PPFD is the measure of the photosynthetic active radiation (PAR) and corresponds to the photon flux density in the $0.40 .7 \mu \mathrm{m}$ waveband. The water stress factor depends on the amount of water contained in the two static reservoirs information given by the hydrological sub-model. Finally, the LAI is simulated as the product of leaf biomass $\mathrm{B}_{l}$, the specific leaf area (SLA) and the vegetation fractional cover as recommended by Pasquato et al. (2015).

\subsubsection{Model inputs}

The inputs of TETIS-VEG model are: climatic data, soil characteristics, CC and Digital Terrain Model (DTM). The climatic data were obtained from SAIH (http://saih.chj.es/chj/saih/) and SIAR (www.siar.es) weather stations. Soil parameters were obtained from Tóth et al. (2017) and the Spanish Mining and Geology Institute (IGME). CC and DTM were performed by using LiDAR (Laser Imaging Detection and Ranging) technology. The LiDAR data was collected in 2009 by PNOA 
(The National Plan of Aerial Ortophotogrammetry, Spanish Government), using an Optech ALS50-II sensor, with a minimum laser pulse rate frequency of $45 \mathrm{kHz}$, a field of view angle of $50^{\circ}$ and a scan rate of $70 \mathrm{~Hz}$. The final density ranged between 0.5 (most of the area) and 2 points $/ \mathrm{m}^{2}$ (flight overlapping). Vertical and planimetric $(\mathrm{X}, \mathrm{Y})$ reported errors were lower than 40 and $36 \mathrm{~cm}$, respectively. $\mathrm{CC}$ is derived from LiDAR data as the proportion of first returns that hit above a specified height threshold (Korhonen et al., 2011), defined in this study as $2 \mathrm{~m}$. It was carried out using gridmetrics tool of Fusion v3.30 software (Fagerberg et al., 2012).

\subsubsection{Calibration and validation of the TETIS-VEG model}

The distributed TETIS-VEG model applies the concept of split-structure for the effective parameter value at each cell (Francés et al., 2007). This calibration strategy consists on an application of a scalar multiplier to each prior parameter field and to estimate the best value for this multiplier via calibration. This so-called multiplier approach makes the assumption that the prior parameter field properly describes the spatial pattern of a specific parameter (the pattern of relative magnitudes from cell to cell), but that the magnitudes of all the parameter values must be adjusted to achieve a better simulation of the model response.

Hence, the effective parameter at each cell (i.e. the parameter value used when running the model) is compounded by two parts: (1) a common correction factor for each type of parameter that takes into account the model, information and input errors and the temporal and spatial scale effects; and (2) the a priori estimated parameter value at each cell. The a priori estimated parameter value was based on the available information (land use maps, soil type, soil depth, among others) and 
expert's knowledge (e.g. Ruiz-Pérez et al. (2016)). Conversely, the correction factors were obtained via automatic calibration. This automatic calibration relied on the SCE-UA (Shuffled Complex Evolution) method as optimization algorithm and the Nash and Sutcliffe efficiency (NSE; Nash and Sutcliffe (1970) index between observed and simulated discharge (CHJSAIH; https://www.chj.es/) as objective function. This automatic calibration was performed within the period from September 2000 to August 2003. To avoid the influence of the previous state, we used one year as warming up period. The accuracy of the model was also validated within the period September 2003 to August 2004.

Once the model is considered calibrated and validated, a specific evaluation of the model performance in predicting transpiration and soil moisture dynamics in the upper catchment area was also carried out by using both field and satellite data. Transpiration was evaluated using daily transpiration data from both experimental plots, control and treatment, and during the water year 2013-2014. The simulated SM dynamics was locally evaluated within the same period, using a Pearson correlation between the simulated and the registered field SM data at each experimental plot. Finally, to evaluate the spatial and temporal performances of SM, the negative natural correlation between temperature and volumetric moisture content under dry conditions was used (Redding et al., 2003). In this way, SM was correlated with the Land-surface temperature calculated from Landsat 8 OLI/TIRS Data following Lian and Huang (2015), in 43 evaluation points randomly distributed and during the years 2013-2017 (Fig. 1). 


\subsection{Model application: eco-hydrological effects of forest management}

The model is firstly used to characterize the current role of the mountainous area as water supplier to the downstream populations. To that end, the ratio between hydrological contribution and public water supply is calculated for the last 10 water years (2007-2017) (Fig. 3). The water years are selected for being representative of the climatic conditions once the forest structure of the Aleppo pine post-fire regeneration stands is considered stable. Subsequently, the model is used to analyze the early effects of forest management of these stands on water yield. To that end, a reduction of the CC from its initial value (obtained with Lidar technology) to $39 \%$, which corresponds to the $\mathrm{CC}$ of the experimental treatment plot, is applied to the 272 ha of Aleppo pine regeneration stands by using QGis software. The effects of forest management in terms of water (ET, deep percolation and runoff) and fire, are considered steady during the first three years after the treatment. A reduction of pine density in semiarid environments implies an increment of the water availability for the remaining trees, and as a consequence, this speeds their growth (Yang, 1998; González-Ochoa et al., 2004; Olivar et al., 2013; Fernandes et al., 2016). This growth increase implies the mitigation of the management effects on water and fire terms, being therefore necessary a new cultural treatment (pruning and/or thinning) within the next 5-10 years (Moya et al., 2008). This study analyzes the early effects of forest management under different water years, as forest management is only applied once. Hence, the 10 water years are used here as independent climatic scenarios to avoid possible bias derived from climate conditions. As a result, different eco-hydrological responses for a precipitation gradient that ranges from 167 to $552 \mathrm{~mm}$ are obtained. 
Finally, a multi-purpose forest management approach that includes water contribution, biomass production and fire risk and propagation diminishing is proposed and analyzed. The biomass production is estimated following (de Serra, 2016). The effect of forest management on wildfire is calculated by using both a modified KDBY index (Garcia-Prats et al., 2015) and the FARSITE software (Finney, 1998). The modified KDBY index is used to estimate the fire risk alteration after forest management. In the same way, according to the fire frequency of the upper catchment area (1.1 fire year $\left.{ }^{-1}\right)$, FARSITE is used to calculate the total burned area of both scenarios, managed and unmanaged, by simulating 10 different forest fires within the 10 water years and during the highest fire risk period (summer). Each fire is simulated 3 times, using 3 different ignition points (upper, middle and lower area) and with a duration between 0.5-2 days.

\subsection{Economic quantification}

The profitability of both management approaches (water yield and multi-purpose) is analyzed by using a simple benefit-cost comparison during the first three years after the treatment, when its effects are considered steady. To that end, three different climatic scenarios, of three years duration each, are considered. The scenarios are generated by means of a MonteCarlo simulation using the climatic data form the last 25 years. Finally, the following simple Benefit/Costs ratio (BC) that considers the expected values of direct costs and benefits is applied to each climatic scenario, using a discount rate of $4 \%$ (Brukas et al., 2001):

$B C=\frac{M V W \cdot W \cdot\left(1-P_{f}\right)+M V W \cdot W_{f} \cdot P_{f}+B V \cdot T B \cdot\left(1-P_{f}\right)+B V \cdot T B \cdot P_{f}}{P_{f} \cdot F E C \cdot B r A+P_{f} \cdot R C \cdot B r A+M C}$ 
where MVW is the Marginal Value of Water $\left(€ \mathrm{~m}^{-3}\right), \mathrm{W}_{f}$ and $\mathrm{W}$ are the water contribution $\left(\mathrm{m}^{3}\right)$ with and without wildfire, respectively, $\mathrm{P}_{f}$ is the probability of a wildfire occurrence, BV is the Biomass Value $\left(€ \mathrm{Mg}^{-1}\right)$, TB is the Total extracted Biomass (Mg), BrA is the Burned Area (ha). FEC are the Fire Extinction Costs (€ $\left.\mathrm{ha}^{-1}\right)$, MC are the Management Costs $\left(€ \mathrm{ha}^{-1}\right)$, and $\mathrm{RC}$ are the restoration costs after a wild fire $\left(€ \mathrm{ha}^{-1}\right) . \mathrm{P}_{f}$ is obtained by considering all the wildfires occurred in the Carraixet's upstream area within the period 1994-2017.

In order to represent the current forest management profitability of the upper catchment area, the economic components of equation 4 are estimated according to the local and/or national references. In this sense, the biomass revenues are estimated at $42 € \mathrm{Mg}^{-1}$, following the local biomass market of the region de Serra (2016)). FEC are estimated as $375.5 € \mathrm{ha}^{-1}$ according to Vázquez et al. (2014). The only MC considered here are those associated to the forest management, which are estimated as $444720 €\left(1635 € \mathrm{ha}^{-1}\right)$ following the local forest management prices (de Serra (2016)). It includes forest thinning, piling and grinding into mulch the small-diameter trees, and biomass transport. The RC are estimated as 6056.74 $€ \mathrm{ha}^{-1}$, which corresponds to the average value of the Spanish post-fire restoration costs during the years 2005-2014. The soil opportunity costs are considered negligible as the forest stands are included into the Natural Park where no soil use change is allowed. The MVW $\left(0.175 € \mathrm{~m}^{-3}\right)$ is assumed as constant Pulido-Velázquez et al. (2013). Finally, a sensitivity analysis of the value of the economic components is performed by increasing it up to double and decreasing it until 0 , using regular intervals. Then, the significant differences between the three climatic scenarios of the managed and unmanaged situations under each economic value are analyzed. 
[Table 1 about here.]

The quantification and analysis of the effectiveness and profitability of the management options (unmanaged, water yield and multi-purpose), is developed by tstudent comparisons when the variables were normal, and the Wilcoxon signed-rank test when normality was not reached. A significance level of $\mathrm{p} \leq 0.05$ is used for all analysis, which are performed by using $\mathrm{R}$ studio software (Team, 2015).

\section{Results}

\subsection{Calibration and validation}

The calibration and validation with the river discharge resulted in NSE indexes equal to 0.7 and 0.4 , respectively. These results can be considered as satisfactory considering the difficulty of simulating intermittent rivers (Snelder et al., 2013; Ivkovic et al., 2014; Costigan et al., 2017). Likewise, the specific evaluation of transpiration and soil moisture dynamics within the experimental plots produced good results in both of them, control and treatment, indicating the good performance of the TETISVEG model in calculating the hydrological cycling of semiarid environments (Table 2 and Fig. 5). On the other hand, the spatial evaluation by comparing Land-surface temperature (derived from Landsat 8 OLI/TIRS Data) with simulated soil water content resulted in a significant negative relationship between both variables (Table 2). These results confirm the capability of the model in reproducing the natural correlation between temperature and soil water content under dry conditions (Redding et al., 2003), and therefore, its reliable performance in semiarid catchments.

[Table 2 about here.] [Figure 5 about here.] 


\subsection{Forest management for water yield increase}

The simulated water years ranged from 167 to $552 \mathrm{~mm}$ of gross precipitation, with an average of $344 \pm 118 \mathrm{~mm}$ (Fig. 4 and table 3). Under these precipitation scenarios, the mountainous upper catchment area showed an average ET of 304.1 100.1 $\mathrm{mm} \mathrm{yr}^{-1}$, which represents $88.7 \pm 5.9 \%$ of the total precipitation. In the same way, the obtained average deep percolation was $27.0 \pm 25.2 \mathrm{~mm} \mathrm{yr}^{-1},(6.8 \pm 3.9 \%)$, and the runoff $12.6 \pm 15.7 \mathrm{~mm} \mathrm{yr}^{-1}(4.5 \pm 6.3 \%)$ (Table 4 ). Particularly, the Aleppo pine postfire regeneration stands showed an average ET of $305.6 \pm 106.0 \mathrm{~mm} \mathrm{yr}^{-1}(89.0 \pm 7.0$ $\%$ ), which is significantly higher than the one obtained in the rest of the upper area, $286.7 \pm 96.8 \mathrm{~mm} \mathrm{yr}^{-1}(83.3 \pm 5.8 \%$ of gross precipitation). On the contrary, the percolation obtained within the regeneration stands $\left(28.97 \pm 22.29 \mathrm{~mm} \mathrm{yr}^{-1}\right)$ is significantly lower than that of the rest of the mountainous area $\left(35.2 \pm 25.3 \mathrm{~mm} \mathrm{yr}^{-1}\right)$.

[Table 3 about here.]

The yearly water extraction from the Carraixet's aquifer to provide drinking water to 6 out of 15 populations ranges from 2.3 to $2.6 \mathrm{hm}^{3}$ year $^{-1}$ (Fig. 4 and table 3 ). The simulated ratio between the upstream contribution (percolation) and the water demand variated from 0.2 to 4.2 , and it only resulted above the unity when the total year precipitation is higher than $345 \mathrm{~mm}$ (Table 3). During the last 10 years, a precipitation equal or higher than this value was registered in 6 years, and in only 3 out of them it was higher than $400 \mathrm{~mm}$, making it difficult the full recovering after a dry water year. Furthermore, the real water demand from the aquifer is not only restricted to drinking water, but also to agricultural irrigation of orange tree, which probably makes the real water demand higher than $2.6 \mathrm{hm}^{3}$ year $^{-1}$ and therefore 
lower contribution/demand ratios.

The early effects of forest management on water contribution were analyzed and quantified by means of simulating a reduction of the $\mathrm{CC}$ from its initial value to 39 $\%$ in the 272 ha of Aleppo pine post-fire regeneration stands. Despite the fact that these stands only represent $18 \%$ of the upper catchment area, the simulated forest management did significantly modify the general water budget, mainly by increasing the average ET (Table 4). This ET increasing was not reflected on percolation nor runoff decrease, but a significant increase of percolation was also obtained. Nevertheless, deep percolation of the managed scenario only exceeded from that of the unmanaged in 6 out of the 10 simulated water years, remaining the same during the rest of the water years (Table 3). The local results at the managed stands followed a similar pattern where a significant increasing of the stand ET is observed, which was also significantly higher than that of the rest of the upper catchment area. In the case of deep percolation, a significant increase during 6 out of the 10 simulated water years was also obtained (Table 3).

This study analyzes the profitability of the forest management approach during the first three years after the treatment by means of a simple benefit-cost comparison (BC function, equation 4). To that end, three different climatic scenarios of three years duration each were simulated and analyzed (Table 5). According to the $\mathrm{BC}$ function, when only the water yield is considered, forest management provides a Benefit/Costs ratio above the unit for the three climatic scenarios, indicating a positive net benefit after three years, in each case. However, this benefit is still sig- 
nificantly lower than the one that would be obtained under the unmanaged scenario, where only the net benefits from water contribution would be accounted, as no $\mathrm{MC}$ are expended.

[Table 5 about here.]

\subsection{Multi-purpose forest management: water yield, biomass and fire risk and prop- agation}

Forest management produces other benefits besides water, whose quantification widely variates in complexity. Two of the direct benefits that can be easily quantified are timber and/or biomass production, and fire risk diminishing. In this study, only biomass production has been estimated as no significant timber is obtained from the first silvicultural treatment of the Aleppo pine post-fire regeneration stands. The biomass production has been estimated in $15.3 \mathrm{~T} \mathrm{ha}^{-1}$ according to (de Serra, 2016), which in total reaches $4161.6 \mathrm{Mg}$ of biomass. Regarding fire, forest management not only decreased fire risk, but also the fire propagation. Both parameters have been calculated in this study by using the modified KBDI index following Garcia-Prats et al. (2015) and the FARSITE software, respectively. The results showed a significant decreasing of the fire risk that reaches $27 \pm 17 \%$, which implies changing from the very high fire risk category to above average fire risk. Likewise, the fire propagation did significantly decrease with the forest management, being the burned area $25.6 \pm 14.1$ $\%$ lower than that of the unmanaged scenario (Table 6). The economic consequences derived from the effects of forest management on wild fire have been estimated just according to the burned area decrease, as the fire risk does not necessarily change in the rest of the upper catchment area, but only in the managed stands. A reduction of the burned area would therefore decrease both, the fire extinction and restoration 
costs.

[Table 6 about here.]

The profitability of the multi-purpose forest management approach that considers water yield, biomass production and fire propagation decrease has been estimated for the three climatic scenarios using equation 4, and under different wildfire durations $(0.5,1,1.5$ and 2 days $)$. As expected, the obtained $\mathrm{B} / \mathrm{C}$ ratios of both management options decreased with the wildfire duration, and were significantly lower than when just considering water yield (see Table 5). Both management options resulted in significantly different $\mathrm{B} / \mathrm{C}$ ratios, except for wildfires of 1 day duration, where no significant differences were obtained. The capability of forest management to improve the $\mathrm{B} / \mathrm{C}$ ratio variates with the wildfire duration. The shortest wildfire $(0.5$ day) shows the unmanagement alternative as the most convenient, while for higher durations (1, 5 and 2 days), the best option appears to be forest management.

The sensitivity analysis (Table 2, 3, 4 and 5 of supplementary material) carried out over the economic components MWV, BV, FEC and RC of equation 4, highlights the relevance of $\mathrm{RC}$, as its increase overturns the advantage of the unmanagement option for the lowest wildfire duration. Likewise, the increase of BV blurs the difference between both alternatives for the same wildfire scenario. MWV also modifies the difference between both alternatives. When no revenues are expected from water yield, forest management becomes the most convenient option for all wildfire durations. On the contrary, the highest values of $\operatorname{MWV}\left(0.3-0.36 € \mathrm{~m}^{-3}\right)$ neglect the difference between both options as no significant B/C ratios are observed. Contrarily, variation of FEC do not produce a significant effect on the difference between 
both management scenarios.

\section{Discussion}

The study uses the TETIS-VEG model (Ruiz-Pérez et al., 2017) to simulate an ephemeral catchment, Carraixet. Despite the fact that hydrological processes of ephemeral streams are of high difficulty to reproduce with simulation models (Snelder et al., 2013; Ivkovic et al., 2014; Costigan et al., 2017), the TETIS-VEG model performance is considered reliable, and it is comparable to the one reached in similar environments. Michaud and Sorooshian (1994) used the KINEROS distributed model in a semi-arid catchment and obtained a RMSE of $22.6 \mathrm{~m}^{3} \mathrm{~s}^{-1}$. Milella et al. (2012) applied a semi-distributed hydrological model in a semiarid Mediterranean river basin, and reported an NSE of 0.52-0.65 and a RMSE of 3.24-3.81 for the reference evapotranspiration. Saber et al. (2015) simulated an arid catchment with the complex distributed model Hydro-BEAM-WaS, and reported a RMSE of $14.58 \mathrm{~m}^{3}$ $\mathrm{s}^{-1}$ and an $\mathrm{R}^{2}$ of 0.89. Adamovic et al. (2016) used the simplified semi-distributed continuous hydrological model SIMPLEFLOOD to simulate a Mediterranean catchment and obtained a general NSE that ranged from -1.05 to 0.76. Furthermore, the results obtained with TETIS-VEG are in agreement with the empirical observations of several studies developed under similar conditions. TETIS-VEG shows a dominance of the ET in the rain partitioning of the upper catchment environment and the Aleppo pine post-fire regeneration stands that fully agrees with the obtained in other studies such as Poole et al. (1981); Domingo et al. (1999); Raz-Yaseef et al. (2012); Ungar et al. (2013); Schlesinger and Jasechko (2014), etc. In the same way, the simulation results showed an increasing of ET after forest management, which according to Raz-Yaseef et al. (2010), it probably responds to an increasing of the 
soil evaporation as the soil radiation exposure is increased.

The simulation results showed the upper catchment area as both, water consumer and water contributor. On the one hand, ET consumes most of the water, while on the other hand, the upstream percolation represents an important water source for the downstream consumers under both management scenarios and the considered precipitation range. These results are consistent with the general assumption about the role of mountain areas as important water providers (Liniger et al., 2005), which in humid environments reaches $20-50 \%$ of downstream freshwater, but in semiarid environments this role rises to 50-90 \% (Liniger et al., 1998; Liniger and Weingartner, 2000; Viviroli et al., 2003), and the primary source of water is the groundwater (Scanlon et al., 2006). Dry environments usually show the most impaired ranges between water resources and water demand (Vörösmarty et al., 2000). The simulation results confirmed this impairment as 4 out of the 10 simulated water years showed a water contribution lower than the downstream urban water demand. Furthermore, if the agricultural water needs are also included into the demand's budget, there would probably be just 2 the years with water surplus, which would increase the potential for conflict over the use of mountain water (Liniger et al., 2005). Thus, a careful management and negotiation of mountain resources must therefore become a priority in order to mitigate growing water crises and conflicts (Liniger et al., 2005).

Forest management of the upper catchment environments has largely been considered as a strategy to increase water yield (Hibbert, 1965; Bosch and Hewlett, 1982 , Troendle, 1983; Troendle et al., 2001; Mark and Dickinson, 2008; McLaughlin et al., 2013). In this study, a significant water yield increase is produced via percolation, mainly as a consequence of the interception decrease. Nevertheless, deep percolation 
only appears to increase under a yearly precipitation above $345 \mathrm{~mm}$, while at lower precipitation values the applied forest management does not modify this budget, although with one exception. There is a precipitation scenario below $345 \mathrm{~mm}$ (232 $\mathrm{mm}$ ) where a percolation increase was observed (Table 3). During this water year, $40 \%$ of precipitation was registered in a single event of $88 \mathrm{~mm}$, which produced $40 \%$ of the total year percolation. Since the CC reduction produces a significant decreasing of the interception loss, this single event produced a significantly higher net precipitation in the managed scenario, which was subsequently percolated within the upper mountainous area. Indeed, if this event is not considered, no percolation increase during the rest of the water year is obtained. These results are in agreement with the studies of Bosch and Hewlett (1982); Hibbert et al. (1982), whom stated that vegetation management in semiarid scrublands is known to be of limited effectiveness when aiming to increase water yield at the catchment scale. Therefore, this precipitation value of $345 \mathrm{~mm}$ per water year, could be considered as a threshold value for water-oriented forest management in semiarid environments, below which no significant increase in water yield is produced. Nevertheless, despite the fact that our results showed a significant water yield increase under precipitations higher than $345 \mathrm{~mm}$ per year, the increase appears not to be high enough to modify the Contribution/Demand ratio. Likewise, in terms of profitability, although the management produces a Cost/Benefit ratio always above the unity when just considering water yield, the profitability of the unamanged scenario is always higher, as there are no management costs to cope with.

Including other benefits, besides water, close to the marketed values into the management of the mountain resources might increase the net benefit, or at least avoid frequent costs such as fire extinction and restoration, reinforcing the manage- 
ment potential of semiarid environments. In this way, the forest management of the mountainous upper catchment area is analyzed and quantified, not just in terms of water resources, but also considering biomass production and fire risk and propagation diminishing. In terms of fire, as stated by several authors (Graham et al., 1999; Hurteau et al., 2008; Navarro et al., 2010; De Cáceres et al., 2015; Garcia-Prats et al. 2015), forest management appears to be an efficient strategy that significantly improves the current situation of wild fire risk and propagation. Regarding to fire risk, it showed a significant decreasing as a consequence of forest management, which is not only reduced in number, but it also produces a change into the fire risk category from the very high fire risk category to above average fire risk. In other words, the applied forest management is reducing the risk of loosing it all in about $27 \%$, which in the upper Carraixet's catchment is very high as lightning is highly frequent and the occurrence of fire in Aleppo pine forests seems to be higher than the average, specially in young stands (Velez, 1986). This accomplishment might be difficult to evaluate in economic terms, but at least it should be considered when managing a catchment, specially if there are populations nearby like in our study site. In the same way, forest management alternatives such as thinning, reduce the fire propagation by decreasing the fuel load (Agee and Skinner, 2005; Hurteau et al., 2008). The obtained results showed a diminishing of about $25.6 \%$ of the burned area under a wild fire, which means that the authorities would avoid $25.6 \%$ of the fire extinction and restoration costs.

Benefits of forest management have been largely studied over the years (Brown et al., 1996; Linder, 2000; González-Ochoa et al., 2004; Nielsen et al., 2007; Moya et al., 2008; Molina and del Campo, 2012; Simonit et al., 2015; Garcia-Prats et al., 2018), although they are usually quantified at stand scale and usually not in eco- 
nomic terms. Presenting forest management as a real alternative to private or public owners implies the development of an economic evaluation that provides information about its viability. This information is even more necessary when dealing with low productive ecosystem such as those located at semi-arid environments, as most of its products are difficult to fit into the traditional forest market. Likewise, quantifying the benefits at catchment scale increases the accuracy of the management viability, as the possible blurring effects are avoided (Wyatt et al., 2015). The results obtained in this study show the multi-purpose forest management which includes water, biomass and fire, as a viable option, whose profitability decreases with wildfire duration. This alternative results more convenient than the unmanaged scenario under important wildfires (1.5-2 days duration), and reveals the need of including more than one benefit into the management approach. On the one hand, managing only for water yield does not generate a more profitable situation than the unmanaged one. Likewise, biomass does also produce revenues, but since the wood is of low quality, these would not even cover the management costs. On the other hand, the economic evaluation shows the fire propagation reduction as a key benefit, as the potential decreasing of $25.6 \%$ of the extinction and restoration costs together with water and biomass production, makes the managed scenario more convenient than the current one.

Furthermore, considering more than one benefit into the management approach could increase the future management efficiency under climate change. On the one hand, the proposed forest management would increase the forest resilience by reducing tree competence and fire risk and propagation, which should draw the attention of policy makers. On the other hand, climate change predictions (higher temperatures and lower precipitation rates in the Mediterranean Basin (Giorgi, 2006)) will modify the current $\mathrm{B} / \mathrm{C}$ ratios. The sensitivity analysis revealed the restoration 
costs as a key element capable of overturning the advantage of the unmanagement alternative under wildfires of 0.5 days duration, followed by the biomass and water revenues. The future influence of climate change on these three elements appears to modify its economic value and/or relevance. An increase of both, temperature and drought periods, will reduce water yield, which according to Pulido-Velázquez et al. (2013) will increase its economic value. Nevertheless, forest management under the established precipitation threshold value of $345 \mathrm{~mm}$ year ${ }^{-1}$ does not significantly increase the water contribution, and the revenues wont differ from the unmanaged situation. In the same way, a drier and warmer environment also bodes a significant increase of wildfire frequency (Westerling et al., 2006, de la Cueva et al., 2012; Alarcón et al., 2015), which would not necessarily increase the RC economic value, but it might increase its magnitude. Finally, the biomass demand is also expected to increase (Berndes et al., 2003; Scarlat et al., 2015; Börjesson et al., 2017), which will probably rise its economic value, and therefore modify the $\mathrm{B} / \mathrm{C}$ ratios in favor of forest management.

The fact that a wildfire of at least 1.5 day duration has to occur to make the multi-purpose forest management as an advantageous option confirms the difficulty that semi-arid forests face. On the one hand, preserving their provision of goods and services needs the urgent application of adaptive management strategies (Fitzgerald et al., 2013), while on the other hand, as the results have shown, the profitability of forest management appears not to be high enough to make it attractive to either public nor private owners. Therefore, the consideration of other benefits but water, biomass and fire propagation, that increases the management profitability becomes necessary to maintain water scarce forests. However, the current forest market services makes it very difficult, as no real revenues can be obtained out of them. Thus, 
probably as long as there is no forest market or public efforts that encourage adaptive management, water scarce forests will continue abandoned and deteriorating under the new climate conditions.

\section{Conclusions}

The results presented in this study confirmed the reliability of the parsimonious distributed model TETIS-VEG as a useful tool, not just to simulate the ecohydrological dynamics of semi-arid catchments, but also to design forest management strategies at catchment scale. Likewise, the study highlights the role of the semiarid mountainous area as main water contributors to downstream users, and identify this catchment as an impaired environment in terms of water yield vs. water demand.

The natural Aleppo pine post-fire regeneration stands are identified as important water consumers, as the obtained ET was significantly higher than that of the rest of the mountainous area. The forest management proposed in these stands resulted in a significant increase of the ET, at the same time that increases the water contribution via percolation. Nevertheless, the results showed a threshold yearly precipitation of $345 \mathrm{~mm}$, below which forest management is not effective in terms of water contribution, as no significant percolation increase is produced. The water contribution/consume ratio after forest management confirmed the low efficiency of this strategy in semi-arid environments. On the contrary, forest management has proven to be an efficient alternative that significantly reduces fire risk and propagation by diminishing both of them, at the same time that produces profitable biomass.

The economic quantification showed the managed scenario as profitable, just considering the water contribution. However, this efficiency in monetary terms is still 
lower than the current situation, where no management costs are considered. Just when fire propagation is included, the results are overturned, and forest management becomes more efficient by avoiding fire extinction and restoration costs. These results reveal the difficulties of semi-arid forests to be managed. In other words, this optimal management should be approached from a multi-purpose perspective that maximizes all the potentials profitability of the forest ecosystem services, which individually cannot be enough efficient from an economical point of view.

\section{Acknowledgements}

This study is a component of the research projects: INTEGRA (CGL2011-28776C02), E-HIDROMED (CGL2014-58127-C3) and CEHYRFO-MED (CGL2017-86839C3-2-R) funded by the Spanish Ministry of Science and Innovation and FEDER funds, and LIFE17 CCA/ES/000063 RESILIENTFORESTS. The authors are grateful to the Valencia Regional Government (CMAAUV, Generalitat Valenciana), the VAERSA staff, the Natural Park staff and the communal authority of Serra (specially Juanjo Mayans) for their support and allowing the use of the Natural Park experimental forest.

\section{References}

M. Adamovic, F. Branger, I. Braud, and S. Kralisch. Development of a data-driven semi-distributed hydrological model for regional scale catchments prone to mediterranean flash floods. Journal of Hydrology, 541:173-189, 2016.

J. K. Agee and C. N. Skinner. Basic principles of forest fuel reduction treatments. Forest Ecology and Management, 211(1):83-96, 2005. 
A. V. Alarcón, J. M. Climent, L. Casais, and J. R. Q. Nieto. Current and future estimates for the fire frequency and the fire rotation period in the main woodland types of peninsular spain: a case-study approach. Forest systems, 24(2):10, 2015.

F. Andersen, editor. Hydrological Modeling in a Semi-arid Area Using Remote Sensing Data. Department of Geography and Geology, University of Copenhagen, Denmark, 2008.

E. Z. Başkent, S. Keleş, A. İ. Kadıoğulları, and Ö. Bingöl. Quantifying the effects of forest management strategies on the production of forest values: timber, carbon, oxygen, water, and soil. Environmental Modeling $\&$ Assessment, 16(2):145-152, 2011.

G. Berndes, M. Hoogwijk, and R. Van den Broek. The contribution of biomass in the future global energy supply: a review of 17 studies. Biomass and bioenergy, 25(1):1-28, 2003.

P. Börjesson, J. Hansson, and G. Berndes. Future demand for forest-based biomass for energy purposes in sweden. Forest Ecology and Management, 383:17-26, 2017.

J. Bosch and J. Hewlett. A review of catchment experiments to determine the effect of vegetation changes on water yield and evapotranspiration. Journal of Hydrology, 55(1):3 - 23, 1982. ISSN 0022-1694. doi: https://doi.org/10. 1016/0022-1694(82)90117-2. URL http://wWw.sciencedirect.com/science/ article/pii/0022169482901172.

S. Brown, J. Sathaye, M. Cannell, and P. E. Kauppi. Mitigation of carbon emissions to the atmosphere by forest management. The Commonwealth Forestry Review, pages 80-91, 1996. 
V. Brukas, B. J. Thorsen, F. Helles, and P. Tarp. Discount rate and harvest policy: implications for baltic forestry. Forest policy and economics, 2(2):143-156, 2001.

S. Burgess, M. Adams, N. Turner, C. Beverly, C. Ong, A. Khan, and T. Bleby. An improved heat pulse method to measure low and reverse rates of sap flow in woody plants. Tree Physiology, 21(9):589-598, 2001.

G. Callegari, E. Ferrari, G. Garfi, F. Iovino, and A. Veltri. Impact of thinning on the water balance of a catchment in a mediterranean environment. The Forestry Chronicle, 79(2):301-306, 2003. ISSN 0015-7546. doi: 10.5558/tfc79301-2.

M. Chiesi, G. Chirici, A. Barbati, R. Salvati, and F. Maselli. Use of biome-bgg to simulate mediterranean forest carbon stocks. Iforest, 4:121-127, 2011.

E. Cienciala and A. Fyodor. Application of biome-bgc model to managed forests 2. comparison with long-term observations of stand production for major tree species. Forest Ecology and Management, 237:252-266, 2006.

K. H. Costigan, M. J. Kennard, C. Leigh, E. Sauquet, T. Datry, and A. J. Boulton. Flow regimes in intermittent rivers and ephemeral streams. In Intermittent Rivers and Ephemeral Streams, pages 51-78. Elsevier, 2017.

M. De Cáceres, J. Martínez-Vilalta, L. Coll, P. Llorens, P. Casals, R. Poyatos, J. G. Pausas, and L. Brotons. Coupling a water balance model with forest inventory data to predict drought stress: the role of forest structural changes vs. climate changes. Agricultural and forest meteorology, 213:77-90, 2015.

A. V. de la Cueva, J. R. Quintana, and I. Cañellas. Fire activity projections in the sres a2 and b2 climatic scenarios in peninsular spain. International Journal of Wildland Fire, 21(6):653-665, 2012. 
E. De Martonne. Une nouvelle fonction climatologique: Lindice daridit. La Meteorologie, pages 449-458, 1926.

A. de Serra, editor. Proyecto de Ordenacion Forestal. Ayuntamiento de Serra, Valencia, Spain, 2016.

A. D. del Campo, M. González-Sanchis, A. Lidón, C. J. Ceacero, and A. García-Prats. Rainfall partitioning after thinning in two low-biomass semiarid forests: Impact of meteorological variables and forest structure on the effectiveness of water-oriented treatments. Journal of Hydrology, 565:74-86, 2018.

F. Domingo, L. Villagarcía, A. Brenner, and J. Puigdefábregas. Evapotranspiration model for semi-arid shrub-lands tested against data from se spain. Agricultural and Forest Meteorology, 95(2):67 - 84, 1999. ISSN 0168-1923. doi: https://doi.org/10.

1016/S0168-1923(99)00031-3. URL http://www.sciencedirect.com/science/ article/pii/S0168192399000313.

P. Duncker, K. Raulund-Rasmussen, P. Gundersen, K. Katzensteiner, J. De Jong, H. P. Ravn, M. Smith, O. Eckmüllner, and H. Spiecker. How forest management affects ecosystem services, including timber production and economic return: synergies and trade-offs. Ecology and Society, 17(4), 2012.

C. Eastaugh, E. Ptzelsberger, and H. Hasenauer. Assessing the impacts of climate change and nitrogen deposition on norway spruce (picea abies l. karst) growth in austria with BIOME-BGC. Tree Physiology, 31(3):262-274, 2011. doi: 10.1093/ treephys/tpr033.

G. Fabbio, M. Merlo, and V. Tosi. Silvicultural management in maintaining bio- 
diversity and resistance of forests in europethe mediterranean region. Journal of Environmental Management, 67(1):67-76, 2003.

J. Fagerberg, D. Mowery, and R. Nelson, editors. Vegetation classification in southern pine mixed hard wood forests using airborne scanning laser point data. Paper SL2012-163 in SilviLaser, Coops, N.C., and M.A. Wulder (eds.), Vancouver, Canada., 2012.

T. J. Fernandes, A. D. Del Campo, R. Herrera, and A. J. Molina. Simultaneous assessment, through sap flow and stable isotopes, of water use efficiency (wue) in thinned pines shows improvement in growth, tree-climate sensitivity and wue, but not in wuei. Forest Ecology and Management, 361:298-308, 2016.

S. Filoso, M. O. Bezerra, K. C. Weiss, and M. A. Palmer. Impacts of forest restoration on water yield: A systematic review. PloS one, 12(8):e0183210, 2017.

M. A. Finney. Farsite: Fire area simulatormodel development and evaluation. Evaluation, 1998.

J. Fitzgerald, J. Jacobsen, K. Blennow, B. Thorsen, and M. Lindner. Climate change in european forests: How to adapt. efi policy brief 9. European Forest Institute, Joensuu, Finland, 2013.

F. Francés, J. I. Vélez, and J. J. Vélez. Split-parameter structure for the automatic calibration of distributed hydrological models. Journal of Hydrology, 332(1):226 240, 2007. ISSN 0022-1694. doi: https://doi.org/10.1016/j.jhydrol.2006.06.032.

F. Gallart and P. Llorens. Catchment management under environmental change: impact of land cover change on water resources. Water International, 28(3):334$340,2003$. 
F. Gallart and P. Llorens. Observations on land cover changes and water resources in the headwaters of the ebro catchment, iberian peninsula. Physics and Chemistry of the Earth, parts A/B/C, 29(11-12):769-773, 2004.

J. Gamon, L. Serrano, and J. Surfus. The photochemical reflectance index: an optical indicator of photosynthetic radiation use efficiency across species, functional types, and nutrient levels. Oecologia, 112(4):492-501, 1997.

A. Garcia-Prats, A. del Campo, F. J. Tarcísio, and M. J. Antonio. Development of a keetch and byrambased drought index sensitive to forest management in mediterranean conditions. Agricultural and forest meteorology, 205:40-50, 2015.

A. Garcia-Prats, A. D. del Campo, and M. Pulido-Velázquez. A hydroeconomic modeling framework for optimal integrated management of forest and water. Water Resources Research, 52(10):8277-8294, 2016. ISSN 1944-7973. doi: 10.1002/2015WR018273. URL http://dx .doi.org/10.1002/2015WR018273.

A. Garcia-Prats, M. González-Sanchis, A. D. Del Campo, and C. Lull. Hydrologyoriented forest management trade-offs. a modeling framework coupling field data, simulation results and bayesian networks. Science of The Total Environment, 639: $725-741,2018$.

F. Giorgi. Climate change hot-spots. Geophysical Research Letters, 33(8), 2006. ISSN 1944-8007. doi: 10.1029/2006GL025734.

A. I. González-Ochoa, F. R. López-Serrano, and J. de las Heras. Does post-fire forest management increase tree growth and cone production in pinus halepensis? Forest Ecology and Management, 188(1):235-247, 2004. 
M. González-Sanchis, A. D. D. Campo, A. J. Molina, and T. J. Fernandes. Modeling adaptive forest management of a semi-arid mediterranean aleppo pine plantation. Ecological Modelling, 308:34 - 44, 2015. ISSN 0304-3800. doi: https://doi.org/10. 1016/j.ecolmodel.2015.04.002. URL http://www.sciencedirect.com/science/ article/pii/S0304380015001325.

C. A. Gracia, E. Tello, S. Sabaté, and J. Bellot. Gotilwa: An integrated model of water dynamics and forest growth. In Ecology of Mediterranean evergreen oak forests, pages 163-179. Springer, 1999.

R. T. Graham, A. E. Harvey, T. B. Jain, and J. R. Tonn, editors. Effects of thinning and similar stand treatments on fire behavior in western forests. USDA Forest Service, Pacific Northwest Research Station, General Technical Report PNW-GTR463, 1999.

A. Hibbert, E. Davis, and O. Knipe, editors. Water yield changes resulting from treatment of Arizona chaparral. In Dynamics and management of Mediterraneantype ecosystems tech. coords. C.E. Conrad and W, C. Oechel. USDA For. Serv. Gen. Tech. Rep. PSW-58, 1982.

A. R. Hibbert. Forest treatment effects on water yield. Citeseer, 1965.

M. D. Hurteau, G. W. Koch, and B. A. Hungate. Carbon protection and fire risk reduction: toward a full accounting of forest carbon offsets. Frontiers in Ecology and the Environment, 6(9):493-498, 2008.

K. Ivkovic, B. Croke, and R. Kelly. Overcoming the challenges of using a rainfallrunoff model to estimate the impacts of groundwater extraction on low flows in an ephemeral stream. Hydrology Research, 45(1):58-72, 2014. 
S. Keleş and E. Z. Başkent. Joint production of timber and water: a case study. Water Policy, 13(4):535-546, 2011.

L. Korhonen, I. Korpela, J. Heiskanen, and M. Maltamo. Airborne discrete-return lidar data in the estimation of vertical canopy cover, angular canopy closure and leaf area index. Rem. Sens. Environ, 115:1065-1080, 2011.

K. Kramer, I. Leinonen, H. H. Bartelink, P. Berbigier, M. Borghetti, C. Bernhofer, E. Cienciala, A. J. Dolman, O. Froer, C. A. Gracia, A. Granier, T. Grnwald, P. Hari, W. Jans, S. Kellomki, D. Loustau, F. Magnani, T. Markkanen, G. Matteucci, G. M. J. Mohren, E. Moors, A. Nissinen, H. Peltola, S. Sabat, A. Sanchez, M. Sontag, R. Valentini, and T. Vesala. Evaluation of six process-based forest growth models using eddy-covariance measurements of $\mathrm{CO} 2$ and $\mathrm{H} 2 \mathrm{O}$ fluxes at six forest sites in europe. Global Change Biology, 8:213-230, 2002. ISSN 1365-2486. doi: 10.1046/j.1365-2486.2002.00471.x.

D. M. Küçüker and E. Z. Baskent. Evaluation of forest dynamics focusing on various minimum harvesting ages in multi-purpose forest management planning. Forest Systems, 24(1):005, 2015.

C. Lampin-Maillet, M. Jappiot, M. Long, C. Bouillon, D. Morge, and J.-P. Ferrier. Mapping wildland-urban interfaces at large scales integrating housing density and vegetation aggregation for fire prevention in the south of france. Journal of environmental management, 91(3):732-741, 2010.

J. Landsberg and R. Waring. A generalised model of forest productivity using simplified concepts of radiation-use efficiency, carbon balance and partitioning. Forest ecology and management, 95(3):209-228, 1997. 
J. Lian and M. Huang. Evapotranspiration estimation for an oasis area in the heihe river basin using landsat-8 images and the metric model. Water Resources Management, 29(14):5157-5170, Nov 2015. ISSN 1573-1650. doi: 10. 1007/s11269-015-1110-z. URL https://doi.org/10.1007/s11269-015-1110-z.

M. Linder. Developing adaptive forest management strategies to cope with climate change. Tree Physiology, 20(5-6):299-307, 2000.

H. Liniger, R. Weingartner, M. Grosjean, and M. Agenda. Mountains of the World: Water Towers for the 21st Century:[a Contribution to Global Freshwater Management]. Mountain Agenda c/o Institute of geography University of Berne, 1998.

H. Liniger, J. Gikonyo, B. Kiteme, and U. Wiesmann. Assessing and managing scarce tropical mountain water resources: The case of mount kenya and the semiarid upper ewaso ng'iro basin. Mountain Research and Development, 25(2):163-173,

05 2005. URL https://search.proquest.com/docview/211223844?accountid= 28445.

H. P. Liniger and R. Weingartner, editors. Mountain forests and their role in providing freshwater resources. CABI Publishing, in association with IUFRO [International Union for Forestry Research Organizations], Wallingford, UK, and New York, USA, 2000.

F. Magnani, L. Consiglio, M. Erhard, A. Nolè, F. Ripullone, and M. Borghetti. Growth patterns and carbon balance of pinus radiata and pseudotsuga menziesii plantations under climate change scenarios in italy. Forest Ecology and Management, 202(1):93-105, 2004. ISSN 0378-1127. doi: 10.1016/j. foreco.2004.07.030. URL http://www.sciencedirect.com/science/article/ pii/S037811270400550X. 
F. Magnani, A. Nolè, F. Ripullone, and J. Grace. Growth patterns of pinus sylvestris across europe: a functional analysis using the hydrall model. iForestBiogeosciences and Forestry, 2(5):162, 2009.

A. F. Mark and K. J. Dickinson. Maximizing water yield with indigenous non-forest vegetation: a new zealand perspective. Frontiers in Ecology and the Environment, 6(1):25-34, 2008.

C. Maroto, M. Segura, C. Ginestar, J. Uriol, and B. Segura. Sustainable forest management in a mediterranean region: social preferences. Forest Systems, 22(3): 546-558, 2013.

D. L. McLaughlin, D. A. Kaplan, and M. J. Cohen. Managing forests for increased regional water yield in the southeastern us coastal plain. JAWRA Journal of the American Water Resources Association, 49(4):953-965, 2013.

B. E. Medlyn. Physiological basis of the light use efficiency model. Tree physiology, 18(3):167-176, 1998.

J. Michaud and S. Sorooshian. Comparison of simple versus complex distributed runoff models on a midsized semiarid watershed. Water resources research, 30(3): 593-605, 1994.

P. Milella, T. Bisantino, F. Gentile, V. Iacobellis, and G. Trisorio Liuzzi. Diagnostic analysis of distributed input and parameter datasets in mediterranean basin streamflow modeling. Journal of Hydrology, 472-473(0):262-276, 2012. ISSN 00221694. doi: 10.1016/j.jhydrol.2012.09.039.

C. I. Millar, N. L. Stephenson, and S. L. Stephens. Climate change and forests of 
the future: managing in the face of uncertainty. Ecological applications, 17(8): 2145-2151, 2007.

R. Mitchell, R. H. Waring, and G. Pitman. Thinning lodgepole pine increases tree vigor and resistance to mountain pine beetle. Forest Science, 29(1):204-211, 1983.

G. Mohren. Simulation of forest growth, applied to Douglas Fir stands in the Netherlands. Dissertation, Agricultural University Wageningen, the Netherlands, p. 184, Parthenon, New York, 1987.

G. Mohren, H. Bartelink, I. Jorritsma, and K. Kramer. A process-based growth model (forgro) for analysis of forest dynamics in relation to environmental factors. M.E.A. Broekmeyer, W. Vos, H. Koop (Eds.), European Forest Reserves. Proceedings of the European Forest Reserves Workshop, 68 May 1992, pp. 273280, The Netherlands, PUDOC, Wageningen, 1993.

A. Molina and A. del Campo. The effects of experimental thinning on throughfall and stemflow: A contribution towards hydrology-oriented silviculture in aleppo pine plantations. Forest Ecology and Management, 269:206-213, 2012.

D. Moya, J. De las Heras, F. López-Serrano, and V. Leone. Optimal intensity and age of management in young aleppo pine stands for post-fire resilience. Forest Ecology and Management, 255(8):3270-3280, 2008.

J. Nash and J. Sutcliffe. River flow forecasting through conceptual models part i a discussion of principles. Journal of Hydrology, 10(3):282-290, 1970.

R. Nathan and G. Ne'eman. Spatiotemporal dynamics of recruitment in aleppo pine (pinus halepensis miller). Plant Ecology, 171(1):123-137, 2004. 
F. B. Navarro, M. Jiménez, E. Cañadas, E. Gallego, L. Terrón, and M. Ripoll. Effects of different intensities of overstory thinning on tree growth and understory plant-species productivity in a semi-arid pinus halepensis mill. afforestation. Forest Systems, 19(3):410-417, 2010.

A. B. Nielsen, S. B. Olsen, and T. Lundhede. An economic valuation of the recreational benefits associated with nature-based forest management practices. Landscape and urban planning, 80(1-2):63-71, 2007.

J. Olivar, S. Bogino, C. Rathgeber, V. Bonnesoeur, and F. Bravo. Thinning has a positive effect on growth dynamics and growthclimate relationships in aleppo pine (pinus halepensis) trees of different crown classes. Annals of Forest Science, pages 1-10, 2013. ISSN 1286-4560. doi: 10.1007/s13595-013-0348-y.

S. V. Ollinger, A. D. Richardson, M. E. Martin, D. Y. Hollinger, S. E. Frolking, P. B. Reich, L. C. Plourde, G. G. Katul, J. W. Munger, R. Oren, et al. Canopy nitrogen, carbon assimilation, and albedo in temperate and boreal forests: Functional relations and potential climate feedbacks. Proceedings of the National Academy of Sciences, 105(49):19336-19341, 2008.

P. Ovando, S. Beguería, and P. Campos. Carbon sequestration or water yield? the effect of payments for ecosystem services on forest management decisions in mediterranean forests. Water Resources and Economics, 2018.

M. Pasquato, C. Medici, A. D. Friend, and F. Francés. Comparing two approaches for parsimonious vegetation modelling in semiarid regions using satellite data. Ecohydrology, 8(6):1024-1036, 2015. ISSN 1936-0592. doi: 10.1002/eco.1559. URL http://dx.doi.org/10.1002/eco.1559. ECO-14-0043.R1. 
D. K. Poole, S. W. Roberts, and P. C. Miller. Water utilization. In Resource use by chaparral and matorral, pages 123-149. Springer, 1981.

F. J. Pulido, M. Diaz, and S. J. H. de Trucios. Size structure and regeneration of spanish holm oak quercus ilex forests and dehesas: effects of agroforestry use on their long-term sustainability. Forest Ecology and Management, 146(1-3):1-13, 2001.

M. Pulido-Velázquez, E. Álvarez-Mendiola, and J. Andreu. Design of efficient water pricing policies integrating basinwide resource opportunity costs. Journal of Water Resources Planning and Management, 139(5):583-592, 2013. doi: 10.1061/(ASCE) WR.1943-5452.0000262.

D. I. Quevedo and F. Francés. A conceptual dynamic vegetation-soil model for arid and semiarid zones. Hydrology and Earth System Sciences Discussions, 4(5):34693499, 2007. URL https://hal .archives-ouvertes.fr/hal-00298896.

P. Quezel. Taxonomy and biogeography of mediterranean pines (pinus halepensis and p. brutia). Ecology, biogeography and management of Pinus halepensis and P. brutia forest ecosystems in the Mediterranean Basin. Backhuys Publishers, Leiden, pages $1-12,2000$.

S. Rambal. Evolution de l'occupation des terres et ressources en eau en région méditerranéenne karstique. Journal of Hydrology, 93(3-4):339-357, 1987.

N. Raz-Yaseef, E. Rotenberg, and D. Yakir. Effects of spatial variations in soil evaporation caused by tree shading on water flux partitioning in a semi-arid pine forest. Agricultural and Forest Meteorology, 150(3):454 - 462, 2010. ISSN 0168- 
1923. doi: https://doi.org/10.1016/j.agrformet.2010.01.010. URL http://www . sciencedirect.com/science/article/pii/S016819231000033X.

N. Raz-Yaseef, D. Yakir, G. Schiller, and S. Cohen. Dynamics of evapotranspiration partitioning in a semi-arid forest as affected by temporal rainfall patterns. Agricultural and Forest Meteorology, 157(Supplement C):77 - 85, 2012. ISSN 0168-1923. doi: https://doi.org/10.1016/j.agrformet.2012.01.015. URL http://www.sciencedirect.com/science/article/pii/S0168192312000469.

T. E. Redding, G. D. Hope, M. J. Fortin, M. G. Schmidt, and W. G. Bailey. Spacial patterns of soil temperature and moisture across subalpine forest-clearcut edges in the southern interior of british columbia. Canadian Journal of Soil Science, 83(1): 121-130, 2003. doi: 10.4141/S02-010. URL https://doi .org/10.4141/S02-010.

J. Rubio, J. Forteza, V. Andreu, and R. Cerni. Soil profile characteristics influencing runoff and soil erosion after forest fire: a case study (valencia, spain). Soil Technology, 11(1):67-78, 1997.

G. Ruiz-Pérez, M. González-Sanchis, A. D. Campo, and F. Francés. Can a parsimonious model implemented with satellite data be used for modelling the vegetation dynamics and water cycle in water-controlled environments? Ecological Modelling, 324:45 - 53, 2016. ISSN 0304-3800. doi: https://doi.org/10. 1016/j.ecolmodel.2016.01.002. URL http://www.sciencedirect.com/science/ article/pii/S0304380016000090.

G. Ruiz-Pérez, J. Koch, S. Manfreda, K. Caylor, and F. Francés. Calibration of a parsimonious distributed ecohydrological daily model in a data-scarce basin by exclusively using the spatio-temporal variation of ndvi. Hydrology and Earth System Sciences, 21(12):6235, 2017. 
S. Sabaté, C. Gracia, and A. Sánchez. Likely effects of climate change on growth of quercus ilex, pinus halepensis, pinus pinaster, pinus sylvestris and fagus sylvatica forests in the mediterranean region. Forest Ecology and Management, 162(1):2337, 2002. ISSN 0378-1127. doi: 10.1016/S0378-1127(02)00048-8.

M. Saber, T. Hamaguchi, T. Kojiri, K. Tanaka, and T. Sumi. A physically based distributed hydrological model of wadi system to simulate flash floods in arid regions. Arabian Journal of Geosciences, 8(1):143-160, 2015.

B. R. Scanlon, K. E. Keese, A. L. Flint, L. E. Flint, C. B. Gaye, W. M. Edmunds, and I. Simmers. Global synthesis of groundwater recharge in semiarid and arid regions. Hydrological Processes, 20(15):3335-3370, 2006. ISSN 1099-1085. doi: 10.1002/hyp.6335. URL http://dx.doi.org/10.1002/hyp.6335.

N. Scarlat, J.-F. Dallemand, F. Monforti-Ferrario, and V. Nita. The role of biomass and bioenergy in a future bioeconomy: policies and facts. Environmental Development, 15:3-34, 2015.

W. H. Schlesinger and S. Jasechko. Transpiration in the global water cycle. Agricultural and Forest Meteorology, 189-190(Supplement C):115 - 117, 2014. ISSN

\ 0168-1923. doi: https://doi.org/10.1016/j.agrformet.2014.01.011. URL http: //wWw.sciencedirect.com/science/article/pii/S0168192314000203.

K. Simonin, T. Kolb, M. Montes-Helu, and G. Koch. The influence of thinning on components of stand water balance in a ponderosa pine forest stand during and after extreme drought. Agricultural and Forest Meteorology, 143(34):266-276, 2007. ISSN 0168-1923. doi: 10.1016/j.agrformet.2007.01.003.

S. Simonit, J. P. Connors, J. Yoo, A. Kinzig, and C. Perrings. The impact of forest 
thinning on the reliability of water supply in central arizona. PloS one, 10(4): e0121596, 2015.

D. A. Sims, H. Luo, S. Hastings, W. C. Oechel, A. F. Rahman, and J. A. Gamon. Parallel adjustments in vegetation greenness and ecosystem co2 exchange in response to drought in a southern california chaparral ecosystem. Remote Sensing of Environment, 103(3):289-303, 2006.

T. H. Snelder, T. Datry, N. Lamouroux, S. T. Larned, E. Sauquet, H. Pella, and C. Catalogne. Regionalization of patterns of flow intermittence from gauging station records. Hydrology and Earth System Sciences, 17(7):2685-2699, 2013.

W. Stogsdili Jr, R. Wittwer, T. Hennessey, and P. Dougherty. Water use in thinned loblolly pine plantations. Forest Ecology and Management, 50(3-4):233-245, 1992.

G. Stoneman. Hydrological response to thinning a small jarrah (eucalyptus marginata) forest catchment. Journal of Hydrology, 150(24):393-407, 1993. ISSN 0022-1694. doi: 10.1016/0022-1694(93)90118-S.

A. Susaeta, D. C. Adams, C. Gonzalez-Benecke, and J. R. Soto. Economic feasibility of managing loblolly pine forests for water production under climate change in the southeastern united states. Forests, 8(3):83, 2017.

R. H. Swanson et al. Managing lodgepole pine ecosystems as watersheds. In Lodgepole Pine: The Species and Its Manage-ment. Symposium Proceedings, pages 305-313, 1984.

F. Tatarinov and E. Cienciala. Application of biome-bgc model to managed forests 1. sensitivity analysis. Forest Ecology and Management, 237:267-279, 2006. 
R.-S. Team. R-studio: integrated development for r. r-studio, inc., boston, ma, usa, 2015.

C. Thornthwaite. An approach toward a rational classification of climate. The Geographical Rev, 38(1):55-94, 1948.

P. Thornton, B. Law, H. L. Gholz, K. L. Clark, E. Falge, D. Ellsworth, A. Goldstein, R. Monson, D. Hollinger, M. Falk, J. Chen, and J. Sparks. Modeling and measuring the effects of disturbance history and climate on carbon and water budgets in evergreen needleleaf forests. Agricultural and Forest Meteorology, 113:185-222, 2002. ISSN 0168-1923. doi: 10.1016/S0168-1923(02)00108-9.

B. Tóth, M. Weynants, L. Pásztor, and T. Hengl. 3d soil hydraulic database of europe at 250m resolution. Hydrological Processes, 31(14):2662-2666, 2017. ISSN 10991085. doi: 10.1002/hyp.11203. URL http://dx.doi.org/10.1002/hyp.11203. HYP-16-0798.R1.

C. A. Troendle. The potential for water yield augmentation from forest management in the rocky mountain region. JAWRA Journal of the American Water Resources Association, 19(3):359-373, 1983.

C. A. Troendle, M. S. Wilcox, G. S. Bevenger, and L. S. Porth. The coon creek water yield augmentation project: Implementation of timber harvesting technology to increase streamflow. Forest Ecology and Management, 143(1-3):179-187, 2001.

E. Ungar, E. Rotenberg, N. Raz-Yaseef, S. Cohen, D. Yakir, and G. Schiller. Transpiration and annual water balance of aleppo pine in a semiarid region: Implications for forest management. Forest Ecology and Management, 298(0):39-51, 2013. ISSN 0378-1127. doi: 10.1016/j.foreco.2013.03.003. 
V. M. C. Vázquez, M. L. Chas Amil, and J. M. Touza. Estimación de los costes de las operaciones de extinción de incendios forestales: Estudio de caso en el distrito forestal de a limia. Revista Galega de Economía, 23(1), 2014.

R. Velez. Fire prevention ia aleppo pine forests. 1986.

O. Viedma, N. Moity, and J. M. Moreno. Changes in landscape fire-hazard during the second half of the 20th century: agriculture abandonment and the changing role of driving factors. Agriculture, Ecosystems \& Environment, 207:126-140, 2015.

D. Viviroli, R. Weingartner, and B. Messerli. Assessing the hydrological significance of the world's mountains. Mountain Research and Development, 23(1):32-40, 2003. ISSN 02764741, 19947151. URL http://www.jstor.org/stable/3674533.

C. J. Vörösmarty, P. Green, J. Salisbury, and R. B. Lammers. Global water resources: vulnerability from climate change and population growth. science, 289(5477):284288,2000 .

A. L. Westerling, H. G. Hidalgo, D. R. Cayan, and T. W. Swetnam. Warming and earlier spring increase western us forest wildfire activity. science, 313(5789): 940-943, 2006.

C. J. Wyatt, F. C. O'Donnell, and A. E. Springer. Semi-arid aquifer responses to forest restoration treatments and climate change. Groundwater, 53(2):207-216, 2015.

R. C. Yang. Foliage and stand growth responses of semimature lodgepole pine to thinning and fertilization. Canadian Journal of Forest Research, 28(12):1794-1804, 1998. 


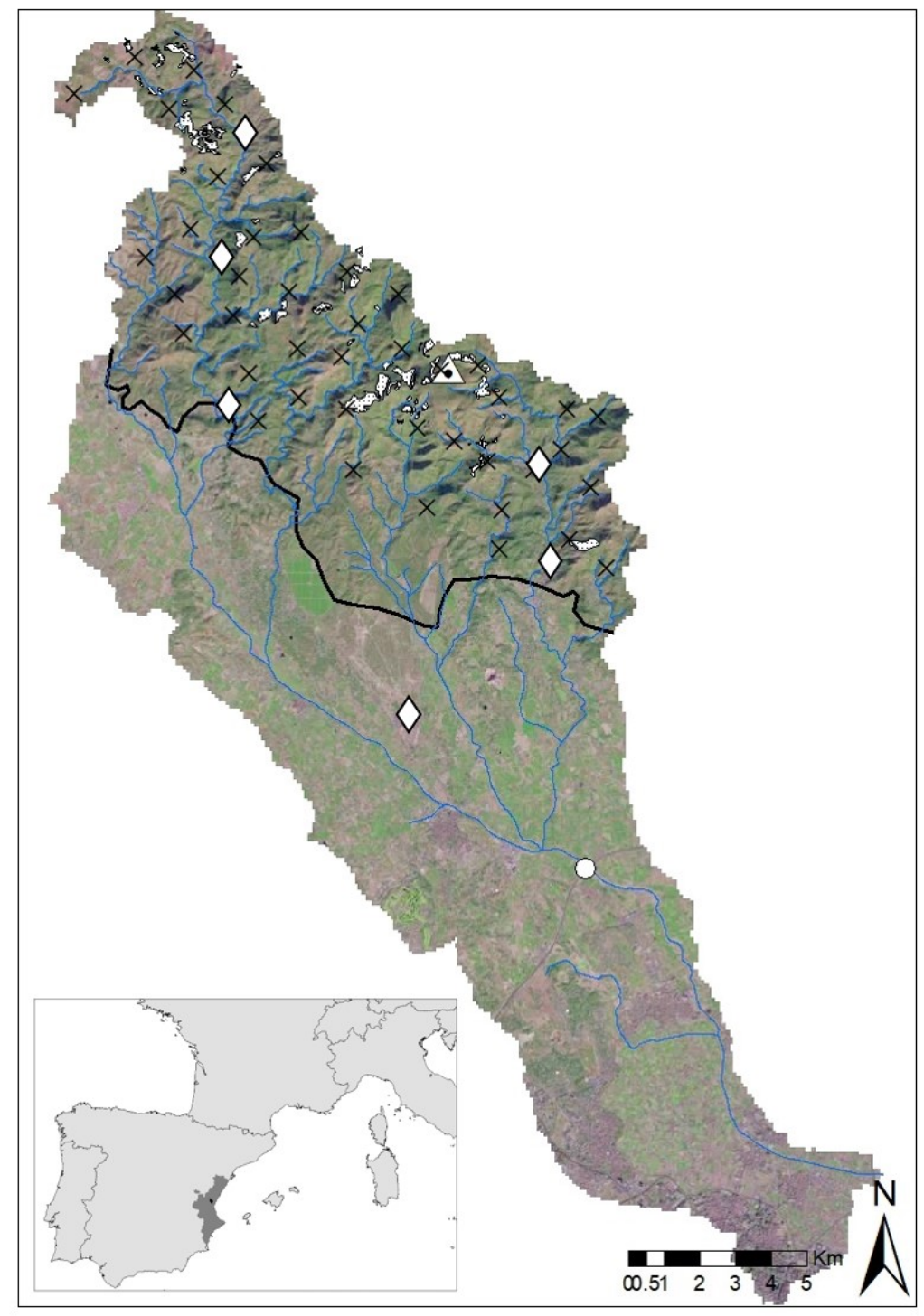

Figure 1: Location of the study site. Black line indicates the lower limit of the mountainous area. $\times$ indicates the location of the soil temperature points used in the model validation. Blue line is the river network. $\triangle$ represents the field experimental plots. $\diamond$ indicates the populations that exclusively use groundwater. $\circ$ indicates the gauging station used during the calibration and validation of the model. Dotted polygons represent the Aleppo pine post-fire regeneration stands. 


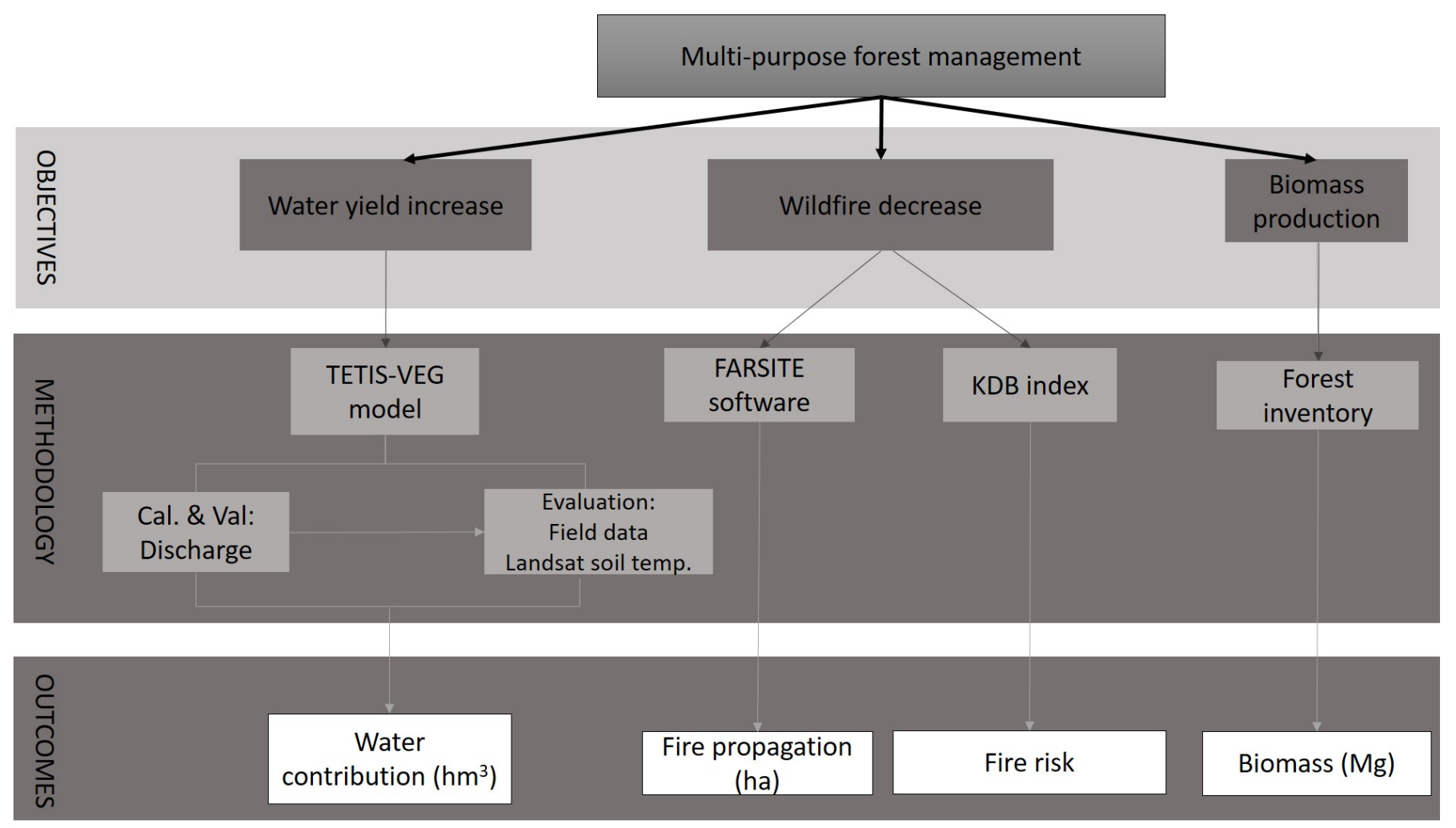

Figure 2: Scheme of the followed methodology. 


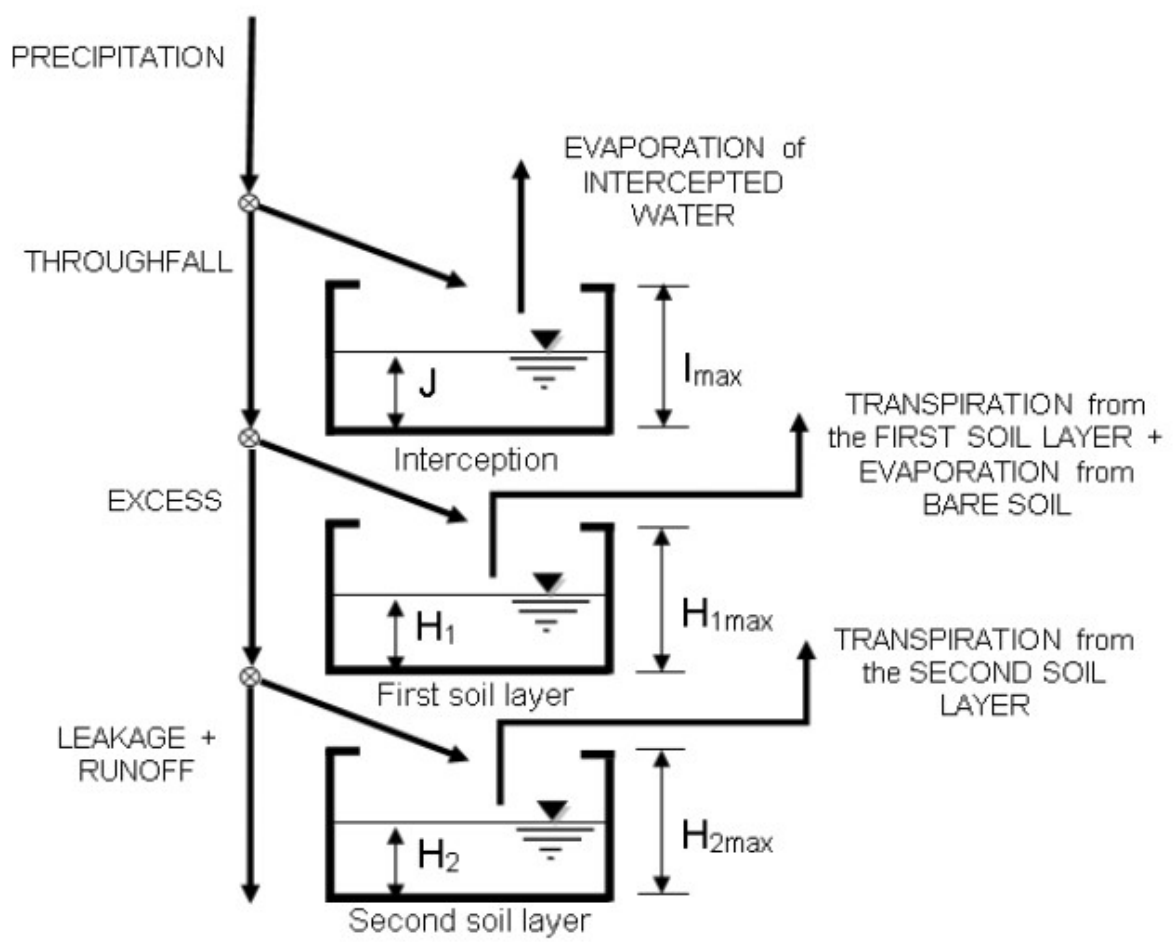

Figure 3: Schema of the hydrological sub-model (Pasquato et al., 2015) 


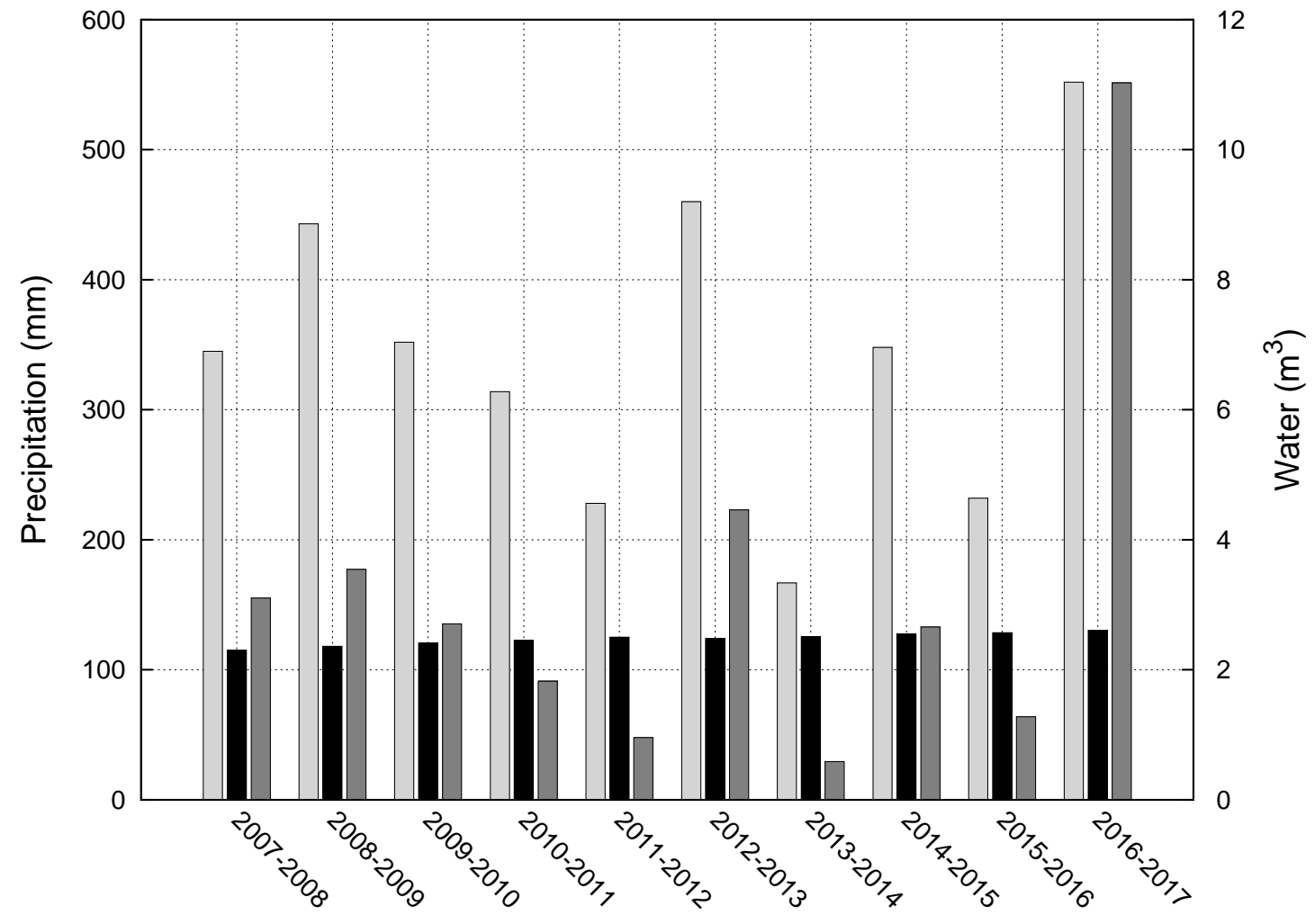

Figure 4: Registered precipitation (light gray), drinking water demand (black) and water contribution of the upper catchment area (dark gray) during the 10 water years at the study site. 

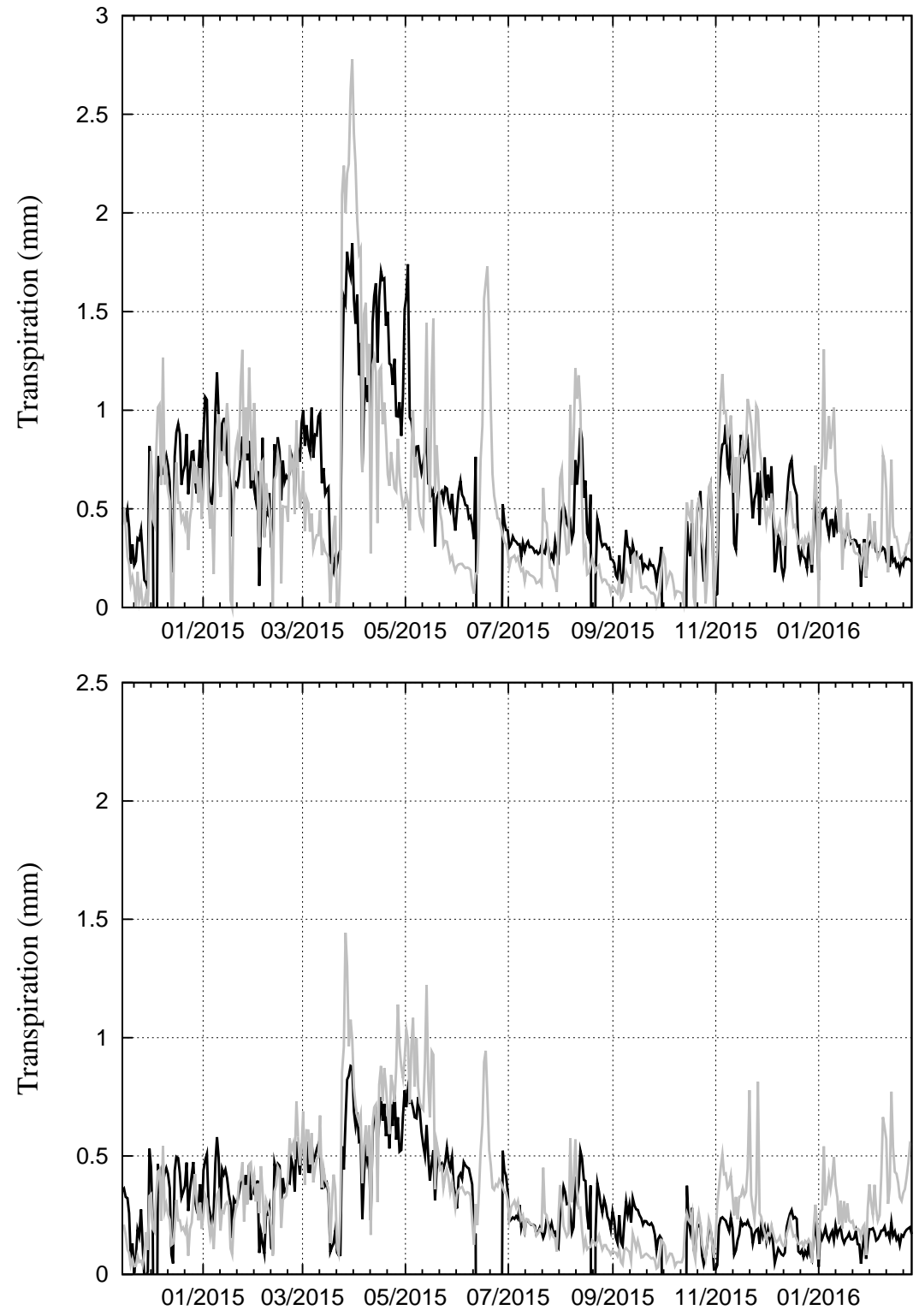

Figure 5: Simulated (gray) and observed (black) stand transpiration at control (upper) and treatment (lower) plots. 
Table 1: Reference prices used in this study. MAGRAMA: Spanish Minister of Agriculture, Food and Environment.

\begin{tabular}{|l|r|r|r|}
\hline Variable & COST & Units & Reference \\
\hline Water (MVW) & 0.175 & $€ \mathrm{~m}^{-3}$ & Pulido-Velázquez et al. $(\overline{2013})$ \\
Fire extinction (FEC) & 375.5 & $€ \mathrm{ha}^{-1}$ & Vázquez et al. $(\overline{2014})$ \\
Restoration (RC) & 6056.74 & $€ \mathrm{ha}^{-1}$ & MAGRAMA \\
Biomass (BV) & 42 & $€ \mathrm{Mg}^{-1}$ & de Serra $(\sqrt{2016})$ \\
Management (MC) & 1635 & $€ \mathrm{ha}^{-1}$ & de Serra \\
\hline
\end{tabular}


Table 2: Calibration and validation results using field and satellite data (Land-surface temperature; Landsat 8 OLI/TIRS). NSE represents the Nash-Sutcliffe coefficient. $p$ represents the Pearson correlation coefficient. RMSE is the Root Mean Square Error.

\begin{tabular}{|l|r|r|r|r|}
\hline Variable & Location & NSE & $\mathrm{p}$ & RMSE \\
\hline \multirow{2}{*}{ Discharge $\left(\mathrm{m}^{3} \mathrm{~s}^{-1}\right)$} & Calibration & 0.70 & 0.50 & 0.47 \\
\hline \multirow{2}{*}{ Transpiration $(\mathrm{mm})$} & Validation & 0.40 & 0.50 & 0.47 \\
\cline { 2 - 4 } & Control & 0.40 & 0.72 & 0.28 \\
\hline \multirow{2}{*}{ Soil moisture $\left(\mathrm{cm} \mathrm{cm}^{-1}\right)$} & Treatment & 0.40 & 0.74 & 0.15 \\
\hline Soil moisture vs Land-surface temperature & Control & - & 0.44 & - \\
\cline { 2 - 4 } & Crandom points & - & $-0.60 \pm 0.11$ & - \\
\hline
\end{tabular}


Table 3: Water contribution as deep percolation of both scenarios, managed and unmanaged, during the 10 water years. Net increasing is the difference between unmanaged and managed deep percolation.

\begin{tabular}{|l|r|r|r|r|r|r|}
\hline \multirow{2}{*}{ Water year } & \multirow{2}{*}{$\mathrm{Gr}(\mathrm{mm})$} & Demand $\left(\mathrm{hm}^{3}\right)$ & \multicolumn{2}{|c|}{ Contribution/Demand } & \multicolumn{2}{|c|}{ Net increasing } \\
\cline { 4 - 7 } & & & Unmanaged & Managed & $\left(\mathrm{m}^{3}\right)$ & $(\mathrm{mm})$ \\
\hline $2007-2008$ & 345 & 2.3 & 1.3 & 1.4 & 8416.7 & 0.71 \\
$2008-2009$ & 443 & 2.4 & 1.5 & 1.5 & 8863.0 & 0.74 \\
$2009-2010$ & 352 & 2.4 & 1.1 & 1.1 & 0 & 0 \\
$2010-2011$ & 314 & 2.5 & 0.7 & 0.7 & 0 & 0 \\
$2011-2012$ & 228 & 2.5 & 0.4 & 0.4 & & 0 \\
$2012-2013$ & 460 & 2.5 & 1.8 & 1.8 & 4375.9 & 0.37 \\
$2013-2014$ & 167 & 2.5 & 0.2 & 0.2 & 0 & 0 \\
$2014-2015$ & 348 & 2.6 & 1.0 & 1.0 & 2767.9 & 0.23 \\
$2015-2016$ & 232 & 2.6 & 0.5 & 0.5 & 4847.4 & 0.41 \\
$2016-2017$ & 552 & 2.6 & 4.2 & 4.2 & 3390.1 & 0.28 \\
\hline
\end{tabular}


Table 4: Evapotranspiration (ET) and percolation values $\left(\mathrm{mm} \mathrm{year}^{-1}\right)$ under the current and the managed scenarios for the total upper catchment area and for the Aleppo pine post-fire regeneration stands.

\begin{tabular}{|l|r|r|r|}
\hline Location & Scenario & ET & Percolation \\
\hline \multirow{2}{*}{ Upper catchment } & Unmanaged & $304.1 \pm 100.1$ & $27.02 \pm 25.20$ \\
\cline { 2 - 4 } & Managed & $304.8 \pm 100.1$ & $27.04 \pm 25.21$ \\
\hline \multirow{2}{*}{ Regeneration stands } & Control & $305.6 \pm 106.0$ & $28.97 \pm 22.29$ \\
\cline { 2 - 4 } & Treatment & $316.7 \pm 103.4$ & $30.13 \pm 27.08$ \\
\hline
\end{tabular}


Table 5: Benefit/Cost ratio of the three different climatic scenarios with and without forest management and under wildfire duration of $0.5,1,1.5$ and 2 days. * indicates significant differences $(\mathrm{p} \leq 0.05)$ between Managed and Unmanaged.

\begin{tabular}{|c|c|c|c|c|c|c|c|c|c|c|}
\hline \multirow{3}{*}{ Scenario } & \multirow{3}{*}{$\mathrm{Gr}(\mathrm{mm})$} & Water & \multicolumn{8}{|c|}{ Water + Biomass + Fire } \\
\hline & & \multirow{2}{*}{ Managed } & \multicolumn{4}{|c|}{ Unmanaged } & \multicolumn{4}{|c|}{ Managed } \\
\hline & & & $0.5 \mathrm{~d}$. & $1 \mathrm{~d}$. & $1.5 \mathrm{~d}$. & $2 \mathrm{~d}$. & $0.5 \mathrm{~d}$. & $1 \mathrm{~d}$. & $1.5 \mathrm{~d}$. & $2 \mathrm{~d}$. \\
\hline \multirow{3}{*}{1} & 299 & \multirow{3}{*}{2.3} & \multirow{3}{*}{1.7} & \multirow{3}{*}{0.7} & \multirow{3}{*}{0.3} & \multirow{3}{*}{0.2} & \multirow{3}{*}{$1.3^{*}$} & \multirow{3}{*}{1.2} & \multirow{3}{*}{$0.4^{*}$} & \multirow{3}{*}{$0.2^{*}$} \\
\hline & 299 & & & & & & & & & \\
\hline & 371 & & & & & & & & & \\
\hline \multirow{3}{*}{2} & 246 & \multirow{3}{*}{1.5} & \multirow{3}{*}{1.1} & \multirow{3}{*}{0.4} & \multirow{3}{*}{0.2} & \multirow{3}{*}{0.1} & \multirow{3}{*}{$0.9^{*}$} & \multirow{3}{*}{0.8} & \multirow{3}{*}{$0.3^{*}$} & \multirow{3}{*}{$0.2^{*}$} \\
\hline & 213 & & & & & & & & & \\
\hline & 312 & & & & & & & & & \\
\hline \multirow{3}{*}{3} & 145 & \multirow{3}{*}{2.2} & \multirow{3}{*}{1.6} & \multirow{3}{*}{0.6} & \multirow{3}{*}{0.3} & \multirow{3}{*}{0.1} & \multirow{3}{*}{$1.3^{*}$} & \multirow{3}{*}{0.7} & \multirow{3}{*}{$0.4^{*}$} & \multirow{3}{*}{$0.2^{*}$} \\
\hline & 221 & & & & & & & & & \\
\hline & 434 & & & & & & & & & \\
\hline
\end{tabular}


Table 6: Burned area (ha) expressed as average \pm standard deviation at the managed and unmanaged scenarios after a wild fire of $0.5,1,1.5$ and 2 days duration.

\begin{tabular}{|l|r|r|}
\hline Duration (day) & Unamanaged & Managed \\
\hline 0.5 & $331.6 \pm 97.1$ & $146.9 \pm 113.2$ \\
\hline 1 & $567.4 \pm 166.4$ & $427.2 \pm 265.9$ \\
\hline 1.5 & $1439.8 \pm 336.2$ & $1122.4 \pm 480.6$ \\
\hline 2 & $1736.7 \pm 422.7$ & $1639.3 \pm 585.7$ \\
\hline
\end{tabular}

